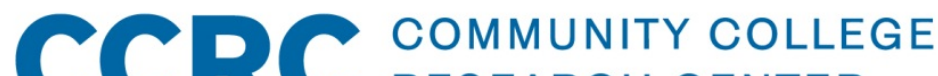 RESEARCH CENTER
}

TEACHERS COLLEGE, COLUMBIA UNIVERSITY

\section{Is School Out for the Summer? The Impact of Year-Round Pell Grants on Academic and Employment Outcomes of Community College Students}

\author{
Vivian Yuen Ting Liu
}

July 2017

CCRC Working Paper No. 95

Address correspondence to:

Vivian Liu

Research Associate, Community College Research Center

Teachers College, Columbia University

525 W. 120th St., Box 174

New York, NY 10027

(212) 678-6639

Email:yt12102@tc.edu

I would like to thank the staff at CCRC for their input and support on earlier drafts of this paper. I especially appreciate suggestions from Jonah Rockoff, Clive Belfield, Judith Scott-Clayton, Thomas Bailey, and participants at the AEFP conference in March 2017. 


\begin{abstract}
Does extra financial aid for the summer lead to gains in completion and earnings? Despite being the largest source of financial aid to low-income college students, the traditional Pell Grant has had one major limitation: if students enroll in two semesters full-time, they will not have any tuition support for the summer term of the same academic year. The year-round Pell (YRP) was implemented in the academic years 2009-10 and 2010-11 to provide a second Pell Grant to students who enrolled in more than 24 credits prior to the third semester and in at least 6 credits during the summer term. This paper employs a difference-in-difference approach to examine the credit, credential completion, and labor market outcomes resulting from the YRP using a state administrative dataset from a community college system. The study finds that for each \$1,000 of YRP grant funding per YRP eligible student, the likelihood of summer enrollment among YRP eligible students increases by 27 percentage points and the likelihood of associate degree completion increases by 2.2 percentage points, with these gains primarily benefitting adult students who enrolled at age 20 or above. Given that the federal government is currently reinstating the YRP, this research is timely in providing insight into the efficacy of the YRP.
\end{abstract}




\section{Table of Contents}

1. Introduction ......................................................................................................................1

2. The Year-Round Pell Grant Program .........................................................................3

2.1 Introduction and Elimination of the Year-Round Pell ................................................3

2.2 Research on the Effect of Need-Based Grants ............................................................

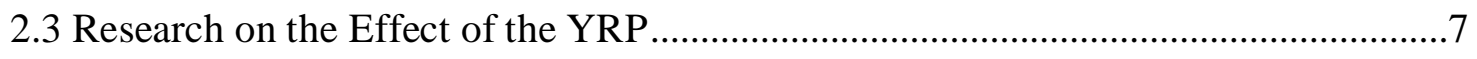

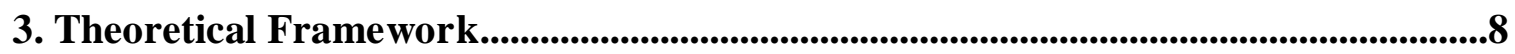

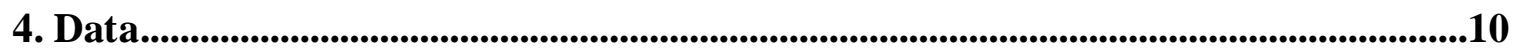

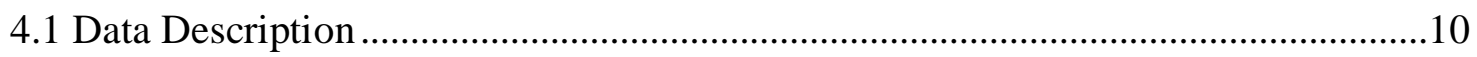

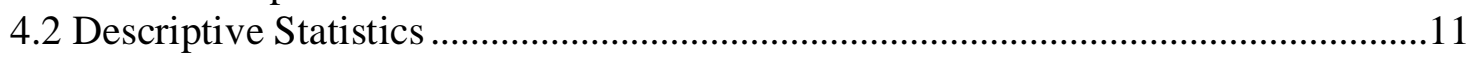

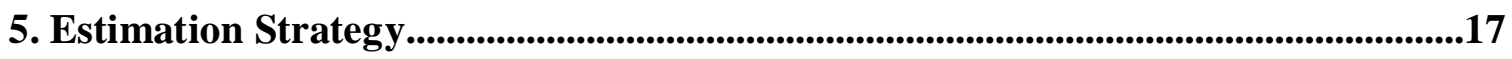

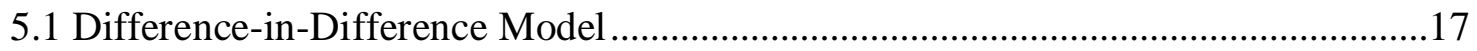

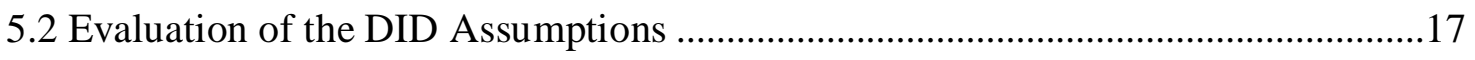

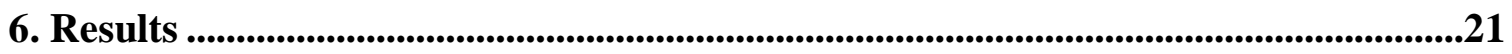

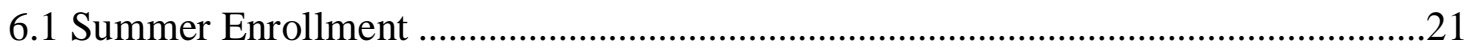

6.2 Credits Earned and Degree Completion..................................................................22

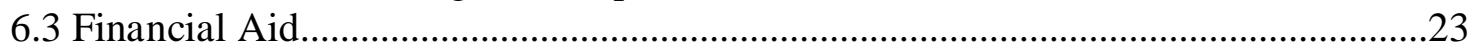

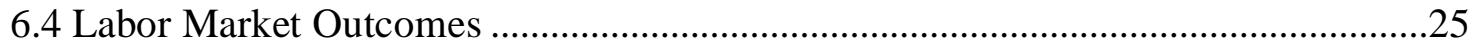

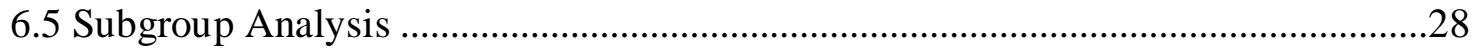

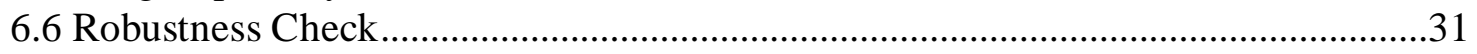

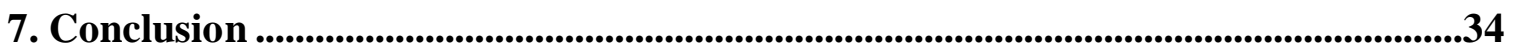





\section{Introduction}

Does extra financial aid for the summer lead to gains in completion and earnings? The Pell Grant is the largest source of financial aid to low-income college students, allocating over \$28 billion in the academic year 2015-2016 to 7.6 million students, most of whom had family incomes below $\$ 50,000$ (Dynarski \& Scott-Clayton, 2013). By lowering the cost of education for low-income students, the goal of the Pell Grant program is to encourage enrollment and completion among those who face the highest financial obstacles. While the traditional Pell Grant covers a substantial proportion of college tuition, the maximum financial aid a student may receive amounts to only two semesters worth of full-time credits without any support for summer courses.

In light of this limitation, the year-round Pell (YRP) was implemented in academic years 2009-2010 and 2010-2011, allowing eligible students during this period to receive a second Pell Grant in the same academic year to cover summer tuition. To ensure that the grant was used toward degree acceleration, students were only eligible for the second award if they attended college full-time for two terms and subsequently enrolled in at least 6 credits in the last (summer) term of the same academic year. After that short period, the YRP program ended. Congress approved restoration of the YRP very recently in May 2017, and in June the Department of Education announced that summer Pell Grants would become available to students beginning July 1, 2017.

Reducing the student cost of education should increase the demand for education, but the literature on the traditional Pell Grant has found only small positive impacts from such education subsidies. Presumably, in these studies the potential positive treatment effects on the overall student population have been diluted by a number of factors, including (1) the exclusion, in regression discontinuity analyses, of non-marginal students around the Pell eligibility cutoff who have higher needs and who receive larger grant awards; (2) the inclusion of eligible students who never apply for financial aid due to the complexity of the application; and (3) the institutional or individual students' responses to increased financial aid, either through colleges absorbing the increase by reducing their 
institutional aid or by students no longer taking loans, both of which hurt student college success. ${ }^{1}$

Given the potential benefits of the YRP and the limited literature on this topic, this study examines the causal effects of the YRP, and it is the first to examine YRP outcomes beyond the first summer, such as short-term credit accumulation, credential attainment, financial aid disbursements, and earnings during college in subsequent terms. The study develops a two-period optimization theoretical model describing how the YRP may influence student decisions about their "credential goals" (for example, "certificate" or "associate degree") based on the projected returns and costs. The introduction of the YRP lowers the cost of summer education; the model thus hypotheses that it should increase summer enrollment. The model also theorizes possible responses from institutions and individuals to the grant. Institutions may attempt to absorb the increase of the grant by reducing institutional support to students. Students may also increase employment while they are enrolled during the fall and spring terms in anticipation of enrolling in summer and having less time to work at that time. But because the increase in funding and the required credits hours associated with the YRP are relatively small, the institutional response and individuals' change in their employment should be minimal. With a lower relative cost of education and an incentive for accelerated credit accumulation, students should graduate at a higher rate and be more competitive after entering the labor market.

Using administrative data on community college students in one anonymous state, I employ a difference-in-difference (DID) approach to compare the difference in the outcomes of full-time and part-time Pell-eligible students enrolling before and after the YRP implementation. While both the full-time and part-time students were eligible for the traditional Pell Grant, only the full-time students-that is, those who enrolled fulltime in the two terms prior to the summer term-were eligible for the YRP once the YRP was implemented.

I find that YRP eligibility increases Pell Grant disbursement in the summer by $\$ 312$ per student, improves the probability of summer enrollment by 8.3 percentage

\footnotetext{
${ }^{1}$ To avoid the first two of these problems, I include already enrolled and Pell-eligible students in the current analysis; I discuss the last issue just below.
} 
points, and leads to 0.7 more credits earned per student in the summer. These improvements in academic support and achievement, in turn, induce completion gains of 3 percentage points in certificates and 0.7 percentage points in associate degrees. The DID estimates show some evidence of the crowding-out effect on institutional or state aid but not loans. In anticipation of summer enrollment, YRP eligible students are also 4 percentage points more likely to work in the fall semester of the first year of enrollment, earning on average \$146 more than non-YRP eligible students. The earnings estimates show a \$681 earnings gain per student in their third year from college entry. Subgroup analysis of the data shows higher short-term credential completion rates for women, higher associate degree graduation rates for men, and larger academic and earnings gains for older versus younger students.

The next section of this paper discusses literature pertaining to the traditional Pell program and the YRP. Section 3 develops a stylized model illustrating the decision YRPeligible students face when choosing an education credential. Section 4 describes the data. Section 5 lays out the DID model and evaluates the underlying assumptions. Section 6 presents the results and robustness checks; conclusions follow in Section 7.

\section{The Year-Round Pell Grant Program}

\subsection{Introduction and Elimination of the Year-Round Pell}

The traditional Pell Grant is a need-based grant, and the maximum disbursement is for 24 credits in one academic year (fall, spring, and summer terms). That means that students exhaust all of the grant with two semesters of full-time enrollment and can only apply the Pell Grant in the summer if they have enrolled in less than 24 credits in that academic year.

The Bush administration signed the YRP into law under the Higher Education Opportunity Act in August 2008. Since the final YRP regulations were not published until October 2009, most colleges did not implement the policy until summer 2010 (U.S. Department of Education, 2012). The purpose of the YRP was to lower the cost of education for low-income students and to accelerate degree completion; therefore, 
students were only eligible for a second Pell Grant if they had completed at least 24 credits in the academic year prior to the summer term covered by the YRP, and if they had also enrolled at least half-time (6 credits) in the last (summer) term of the academic year.

The YRP provided access to a second Pell Grant in the same academic year. Its disbursement was calculated in the same way as for the traditional Pell: by evaluating the Expected Family Contribution (EFC), student cost of attendance, and number of enrolled credits for the term. The maximum disbursement the student could receive via the YRP was therefore the same as the maximum Pell Grant disbursement he or she received for a term of full-time enrollment.

An estimated 1.2 million Pell Grant recipients benefited from the YRP in academic year 2009-2010, receiving an additional \$1,700 on average for their second grant (Congressional Budget Office, 2013). The total cost was approximately $\$ 2$ billion, amounting to 6 percent of the total Pell Grant disbursements for that year.

The federal government eliminated the YRP effective July 1, 2011, due to a "lack of evidence" of its effectiveness and due to a cost that was twice what had been expected (Office of Management and Budget, 2011; U.S. Department of Education, 2011). Elimination of the YRP helped to meet the $\$ 11.2$ billion funding shortfall in the Pell Grant program, whose cost had nearly doubled from $\$ 18.2$ billion to $\$ 35.6$ billion between academic years 2008-09 and 2010-2011 (U.S. Department of Education, 2013).

After numerous legislative initiatives, Congress has reinstated the YRP for fiscal year 2017 under the omnibus appropriation budget bill. The final regulation has yet to be published, but no indication suggests that it would be significantly different from the YRP implemented previously. The U.S. Department of Education recently announced that summer Pell Grants would become available to students beginning July 1, 2017.

\subsection{Research on the Effect of Need-Based Grants}

Grant disbursements should theoretically reduce the cost of education to students and therefore increase the quantity demand for college, but so far the empirical evidence has shown at most only small positive impacts from such education subsidies. In contrast, some studies have found that the traditional Pell Grant has no impact on enrollment (Carruthers \& Welch, 2015; Hansen, 1983; Kane, 1995; Rubin, 2011), credit 
accumulation, or degree attainment (Marx \& Turner, 2017). Based on recent studies, a growing number of academics have found an enrollment increase of 3-6 percent per \$1,000 in grant disbursement from various sources (Deming \& Dynarski, 2010). Focusing mostly on traditional-age students, these quasi-experimental studies examined grants provided by the federal Social Security benefit program (Dynarski, 2003), state scholarships (Abraham \& Clark, 2006; Castleman \& Long, 2016; Dynarski, 2000, 2004; Goldrick-Rab, Kelchen, Harris, \& Benson, 2016; Kane, 2003), and Pell Grants (Alon, 2011; Bettinger, 2004; Seftor \& Turner 2002) using national and state data.

Several factors have been shown to cause an underestimation of the estimated impact of the Pell Grant in particular. First, many studies on the effects of Pell Grants mentioned above (Alon, 2011; Bettinger, 2004; Seftor \& Turner 2002) use a regression discontinuity approach, which focuses on the local average treatment effect only among the marginal students around the eligibility cutoff. This is significant because the grant size is smaller around the threshold, and higher need students are not included in the analysis. In contrast, the subset of studies that looked specifically at nontraditional students, such as older students, veterans, and students from the bottom half of the income distribution, found positive gains (Alon, 2011; Barr, 2015; Bound \& Turner, 2002; Denning, 2017; Lovenheim \& Owens, 2014; Seftor \& Turner 2002).

Second, the complexity of financial aid applications has undermined aid effectiveness and disproportionally harmed the individuals that need it the most (Bettinger, Long, Oreopoulos, \& Sanbonmatsu, 2012; Dynarski \& Scott-Clayton, 2006; Dynarski \& Scott-Clayton, 2008; Kane, 1994). Due to the challenge of simply applying for federal aid, many eligible low-income students simply pass on the opportunity to apply for or receive a Pell Grant. The average impact of the Pell Grant is contingent on the percentage of students participating in the financial aid program. By including students that are already receiving financial aid, the analysis that follows in this paper ensures a more accurate estimation of the effect of the YRP.

Third, some colleges increase Pell Grant recipients’ net tuition cost by reducing institutional grants in order to capture the federal aid (Fullerton \& Metcalf 2002; Turner 1998). Turner (2014) estimated that institutions on average crowded out 12 percent of Pell Grant funding through price discrimination, with the capture rate lowest at public 
colleges and highest at private nonprofit colleges. Such institutional aid crowding reduces the impact of Pell Grants because students are not receiving the full benefits.

Finally, Marx and Turner (2017) have suggested that grant aid reduces the need for loans and that in the presence of an opt-in cost, some students may stop borrowing, which in turn may actually reduce education attainment, thereby offsetting the expected gains in enrollment and completion from grant aid. They showed that each dollar of Pell Grant reduces loans by $\$ 1.8$ among borrowers in a university system with a fixed cost of borrowing. Their results suggest that the increase in Pell Grant funding might make it no longer worthwhile to pay the fixed cost of a smaller loan and that the impact from Pell Grants should be larger in the absence of a loan crowding-out effect.

Most of the papers mentioned above focus on academic outcomes. Very little research has looked at the impact of Pell Grants on non-academic outcomes. While a few papers have considered the effect of Pell Grants on other financial aid, only one has examined the impact of Pell Grants on labor market outcomes. Using state administrative data from academic years 2003-04 to 2013-14, Denning (2017) identified a discontinuity in dependency and financial aid status. Students who were 24 years of age on January 1 were independent for financial aid purposes and received a higher amount of aid compared to those who were still 23 and a dependent on January 1. The increase in financial aid resulted in a shorter time to degree and lower employment during college.

The Pell literature sheds light on several important points regarding the analysis of the YRP. First, the impact of the YRP should be larger than the previous estimates for the traditional Pell Grants, especially when looking at all Pell recipients and not just the marginal students when using regression discontinuity methods. The impact should also be larger when focusing on nontraditional students sensitive to college price or students at public colleges with low grant capture rates. Also, when a comparison is made among students who already have access to the Pell program, the complexity of the application may be less of a barrier to enrollment for the YRP. Furthermore, the eligibility requirement of the YRP provides an incentive to accumulate more credits, which should theoretically produce better outcomes than the traditional Pell Grant, which has no such provision. Finally, Denning (2017) and Marx and Turner (2017) illustrated the importance of looking at other student behavior in addition to academic outcomes. 


\subsection{Research on the Effect of the YRP}

A handful of studies have examined the YRP (Katsinas, Davis, Friedel, Koh, \& Grant, 2011; Katsinas, Davis, Joh, \& Grant, 2012; Bannister \& Kramer, 2015;

Friedmann, 2016), but only two studies have used causal methods. Using repeated crosssectional data from 4,900 students from one community college in Florida, Bannister and Kramer (2015) compared the difference of summer credit completion of YRP and nonYRP participants before and after the implementation of the YRP. Most of the variation comes from students who were eligible for the YRP and enrolled both before and during the implementation of the YRP. They found that the YRP on average increased summer enrollment by 1.5 credits per student. Yet the ability to generalize from their results may be limited as they used data from only one college. Comparing student outcomes across years may potentially be problematic as student outcomes in their initial years of enrollment are often different from their outcomes in the later years. Using the same methods but data from all colleges in the California Community College system, Friedmann (2016) showed that the YRP led to an increase in summer credit enrollment of 0.4 credits per student on average. However, Friedmann did not find an increase in the external margin of students enrolling in the summer or in the percentage of students earning over 6 credits in the summer, an eligibility requirement for the YRP. That means that the YRP only encouraged a heavier summer credit load among students who would have taken summer courses anyway, without influencing the overall percentage of students enrolling in summer courses. Though the studies have results that are consistent with each other, a major limitation of these studies is the lack of outcomes measured beyond the first summer. As Marx and Turner (2017) have demonstrated, the positive effect of Pell Grants on enrolled credits per student does not necessarily translate into a detectable effect on credit accumulation or degree completion.

More research is needed to fully understand the impact of the YRP and the traditional Pell Grant. The traditional Pell Grant literature up to this point suffers from numerous limitations: many papers are based on data from close to two decades ago, ${ }^{2}$ follow-up periods are too short, and the range of outcomes evaluated are too narrow, with

\footnotetext{
${ }^{2}$ Note, however, that four papers on the YRP use more recent data (Denning, 2017; Goldrick-Rab, Kelchen, Harris, \& Benson, 2016; Max \& Turner, 2017; and Rubin, 2011).
} 
only one paper looking at the effect of the Pell Grant on students' loan patterns (Marx \& Turner, 2017) and one evaluating its impact on labor market outcomes (Denning, 2017). The present study fills in some of the gaps in the literature by (1) using a DID approach and administrative data from one statewide community college system to look for the first time at the effect of the YRP on outcomes after the first summer such as degree completion and labor market outcomes; (2) focusing on community college students, who are predominately nontraditional and low-income students; and (3) estimating the impact of the YRP on loans, other non-Pell financial aid, and employment patterns during enrollment.

\section{Theoretical Framework}

The introduction of the YRP provides a second Pell for eligible students to use toward summer tuition. Students must have already been Pell recipients, enrolled fulltime in the fall and spring semesters, and enrolled at least half-time in the summer to be eligible for the YRP. The relative student cost to enrolling year-round and full-time was therefore lower after the implementation of the YRP. Building on previous literature, I develop a stylized two-period optimization model to predict the impact of the grant on students' academic and employment outcomes.

To formalize the model, let person $i$ 's cost of education $\left(T_{i}\right)$ in the first period be the difference between the sticker tuition price $\left(t_{k}\right)$ and Pell reimbursement. The Pell Grant contains two components: the year-round $\left(t_{Y R P_{i}}\right)$ and traditional Pell reimbursement $\left(t_{P_{i}}\right)$. The higher the Pell Grant reimbursement, the lower the net tuition the student pays, and the more credits the student takes. A key assumption is that students do not engage in credit-smoothing behavior as a result of the YRP. For example, the YRP would have no academic effect on an individual if he or she takes 15 credits each in the fall and spring semesters in the absence of the YRP versus 12 credits each in the fall and spring semesters and 6 credits in the summer with the YRP. In both cases, this individual enrolls in 30 credits over the entire academic year and merely allocates the credit hours differently to enjoy a lower relative cost. 
The cost of education varies with the level of education $\left(E_{i}\right)$ Pell Grant recipients choose, which ranges from 1 to $K$. The set $K$ contains the different levels of schooling individuals can attain, including some credits, certificates, diplomas, and associate degrees. Since the credit requirement increases with $K$, tuition $\left(t_{k}\right)$ also rises monotonically with $K$.

$$
T_{i}=\sum_{k=1}^{K} \operatorname{Max}\left[t_{k}-t_{Y R P_{i}}-t_{P_{i}}, 1\right] \cdot 1\left\{E_{i}=k\right\}
$$

Income, or the opportunity cost, of education in the first period $\left(Y_{i}\right)$ is modeled as the sum of earnings during enrollment and other non-Pell Grant subsidies $\left(S_{i}\right)$. The model allows both components to vary with the level of education chosen. The term $\gamma \cdot t_{Y R P_{i}}$ takes into account any crowding-out effect on institutional or state aid by the YRP, in which an institution or state tries to absorb the increase in Pell Grant aid by reducing financial assistance to students. Both $\beta$ and $\gamma$ are positive, between zero and one. The opportunity cost of enrolling in more schooling increases with $K$.

$$
Y_{i}=\left(\beta Y_{i}+\left(1-\gamma \cdot t_{Y R P_{i}}\right) S_{i}\right) \cdot 1\left\{E_{i}=k\right\}
$$

Using the definition in equations (1) and (2), the budget constraints in the initial period are:

$$
c_{i 1} p_{c}+T_{i} \leq Y_{i}+h_{i}
$$

where the consumption in non-education goods and education net of the Pell Grant disbursement is no more than the sum of current income, net tuition subsidies other than the YRP, and net saving or borrowing from the future income. $h$ could be invested or borrowed at an interest rate of $r$.

The budget constraint for the second period is:

$$
c_{i 2} p_{c} \leq w_{i} \mid E_{i}-h_{i}(1+r)
$$


An individual will receive future return $w_{i} \mid E_{i}$ conditional on the level of education chosen. The consumption in the second period will be less than or equal to his or her future wages and net savings plus interest.

Granting that the hours of work and leisure are fixed, all Pell Grant recipients face the following two-period optimization condition:

$$
\max V\left(c_{i 1}, E\right)=u\left(c_{i 1}\right)+\propto u\left(c_{i 2}\right)
$$

subject to budget constraints in equations (3) and (4). To maximize utility from consumption, individuals choose $E$ weighting on $w_{i} \mid E_{i}$ and the cost of attaining it.

The model yields the following hypotheses regarding the introduction of the YRP for YRP eligible students: (1) As seen in equation 1, the YRP lowers the net cost of education and should lead to higher levels of summer enrollment and credit accumulation assuming students do not participate in credit-smoothing behavior; (2) with increased credit accumulation as a result of the YRP, student persistence and graduation rates will increase; (3) equation 2 indicates that the YRP may lead to a crowding-out effect on state or institutional financial aid, yet given that community colleges are the least likely to increase their tuition to absorb increased grants (Turner, 2014), the institutional crowding-out effect should be minimal; (4) the requirement for the YRP in the summer is 6 credits or about two courses, which should not have a large effect on income during enrollment; and (5) with increased graduation rates, students using the YRP will have higher earnings after leaving college.

\section{Data}

\subsection{Data Description}

The sample in this study consists of four cohorts of first-time degree-seeking students who enter the community college system of an anonymous state in the fall semesters of 2006-2009. Students can earn three types of credentials: certificates (12-18 credits), diplomas (36-48 credits), and associate degrees (64-76 credits). The data 
includes demographic characteristics, transcripts, financial aid, and credential information up to the summer of 2010. Additional credential data is obtained through the National Student Clearinghouse (NSC), including data from any public or private college up through February 2012. In addition, quarterly earnings adjusted to 2010 dollars and industry codes are available between 1996 and the first quarter of 2012.

The comprehensive nature and the large sample size of this dataset make it well suited to answer the study's research questions. Completion and labor market results are followed for up to at least 2.5 years after enrolling in college for the first time. This data also enables the observation of term-by-term variations of students' attainment of credits, financial aid behavior, and employment patterns during the first year of enrollment.

With the goal of evaluating the impact of the YRP on college degree seekers, I restrict the sample to Pell recipients enrolled in a community college credential program, thereby dropping individuals in enrichment or high school programs. I also drop students intending to transfer because the data do not provide any transcripts for transfer students. And although the NSC data provides information on degree attainment outside of the community college system, the short follow-up period makes it impossible to observe any bachelor's degree attainment.

\subsection{Descriptive Statistics}

Table 1 provides the descriptive statistics for the sample, displaying student characteristics, academic outcomes, and labor market statistics for students enrolling before and during 2009 by enrollment status in the first term. The student composition of this sample is typical of most community college systems, with a high proportion of minority, low-income, and older students. Up to 50 percent of the student body is nonWhite. Age of enrollment varies from 18 to 50 with a median of 22. Over 60 percent of students have zero expected family contribution (EFC) and therefore are eligible to receive the maximum Pell Grant.

The demographic characteristics of full-time and part-time students look similar, except that full-time students are less likely to be Black. Full-time students also have more credits earned, higher grade point averages (GPAs), and higher completion rates.

Compared with students enrolled prior to 2009, those who entered in 2009 are slightly older and demonstrate higher financial need. They are also slightly less likely to 
be employed the year prior to entering college. If employed, students in the 2009 cohort earned less than those in the cohorts entering before 2009.

YRP eligible students are full-time students who enrolled in 2009. They are at least 10 percentage points more likely to enroll and earn over 6 credits in the summer than full-time students in the previous years.

To better understand the distribution of the Pell Grant, Figure 1 summarizes the Pell Grant disbursements by enrollment status, year enrolled, and EFC, and Figure 2 summarizes student characteristics by cohort. Panel A in Figure 1 shows evidence that full-time students who enrolled prior to 2009 exhausted their Pell Grant before the first summer. After implementation of the policy, full-time students who enrolled in 2009 were able to receive a second Pell Grant for the summer. Additionally, while Panel B shows that the increase in maximum Pell Grant disbursements in 2009 raised the total Pell awarded by similar amounts for full-time and part-time students in the fall and spring semesters, Panel A indicates that the increase is much larger in the summer for full-time students (after implementation of the YRP policy).

Table 2 summarizes the credits earned and Pell Grant disbursements for YRP recipients who enrolled in 2009 with full-time enrollment in the fall and spring semesters and who still received Pell Grants in the summer. On average, they earned 14 credits in the fall and spring semesters, which is more than the full-time requirement of 12 credits. The total credits earned in the summer ranged between 3 and 20 credits with a mean of 8 credits. Over 71 percent of the YRP recipients earned over 6 credits in the summer. Finally, Table 2 also indicates that the amount of average YRP disbursement is substantial: over $\$ 1,500$, or 66 percent of the amount received in fall or spring semesters. 
Table 1

Summary Statistics of Cohorts Enrolling Between 2006 and 2009

\begin{tabular}{|c|c|c|c|c|}
\hline \multirow[b]{2}{*}{ Variable } & \multicolumn{2}{|c|}{ Enrolled Prior to 2009} & \multicolumn{2}{|c|}{ Enrolled in 2009} \\
\hline & Full-Time & Part-Time & Full-Time & Part-Time \\
\hline Observations & 7,908 & 8,183 & 5,434 & 5,073 \\
\hline \multicolumn{5}{|l|}{ A. Students Characteristics } \\
\hline Female & $69 \%$ & $70 \%$ & $63 \%$ & $65 \%$ \\
\hline Black & $34 \%$ & $46 \%$ & $33 \%$ & $48 \%$ \\
\hline Hispanic & $3 \%$ & $3 \%$ & $4 \%$ & $4 \%$ \\
\hline Other race/ethnicity & $8 \%$ & $9 \%$ & $7 \%$ & $7 \%$ \\
\hline Single parent & $8 \%$ & $8 \%$ & $7 \%$ & $6 \%$ \\
\hline High school graduate & $94 \%$ & $93 \%$ & $93 \%$ & $91 \%$ \\
\hline Disabled & $2 \%$ & $2 \%$ & $1 \%$ & $1 \%$ \\
\hline Age at enrollment & 25 & 26 & 27 & 26 \\
\hline Age over 19 at enrollment & $57 \%$ & $59 \%$ & $66 \%$ & $65 \%$ \\
\hline Zero expected family contribution & $57 \%$ & $61 \%$ & $62 \%$ & $71 \%$ \\
\hline Expected family contribution in term 1 & 942 & 757 & 874 & 587 \\
\hline Pell amount in term 1 & 1,918 & 1,578 & 2,347 & 1,939 \\
\hline \multicolumn{5}{|l|}{ B. Academic outcomes } \\
\hline GPA term 1 & 3.09 & 2.08 & 3.13 & 1.98 \\
\hline GPA year 1 & 2.89 & 1.97 & 2.93 & 1.89 \\
\hline Credits earned term 1 & 14 & 6 & 13 & 6 \\
\hline Credits earned year 1 & 25 & 11 & 26 & 11 \\
\hline Enrolled first summer & $29 \%$ & $15 \%$ & $41 \%$ & $17 \%$ \\
\hline Credits enrolled first summer & 2 & 1 & 3 & 1 \\
\hline Credits earned first summer & 2 & 1 & 3 & 1 \\
\hline Earned over six credits in summer & $15 \%$ & $4 \%$ & $25 \%$ & $7 \%$ \\
\hline Earned certificate within 2.5 years & $5.3 \%$ & $1.7 \%$ & $6.1 \%$ & $1.5 \%$ \\
\hline Earned diploma within 2.5 years & $3.4 \%$ & $0.9 \%$ & $3.9 \%$ & $0.6 \%$ \\
\hline Earned associate degree within 2.5 years & $4.5 \%$ & $0.5 \%$ & $5.7 \%$ & $0.5 \%$ \\
\hline \multicolumn{5}{|l|}{ C. Employment } \\
\hline Ever employed 1 year prior to college & $73 \%$ & $77 \%$ & $67 \%$ & $69 \%$ \\
\hline Earnings if employed 1 year prior to college & 6,576 & 7,632 & 6,520 & 6,662 \\
\hline
\end{tabular}




\section{Figure 1}

Pell Amount by Expected Family Contribution

A. Pell Amount in the First Summer by Expected Family Contribution
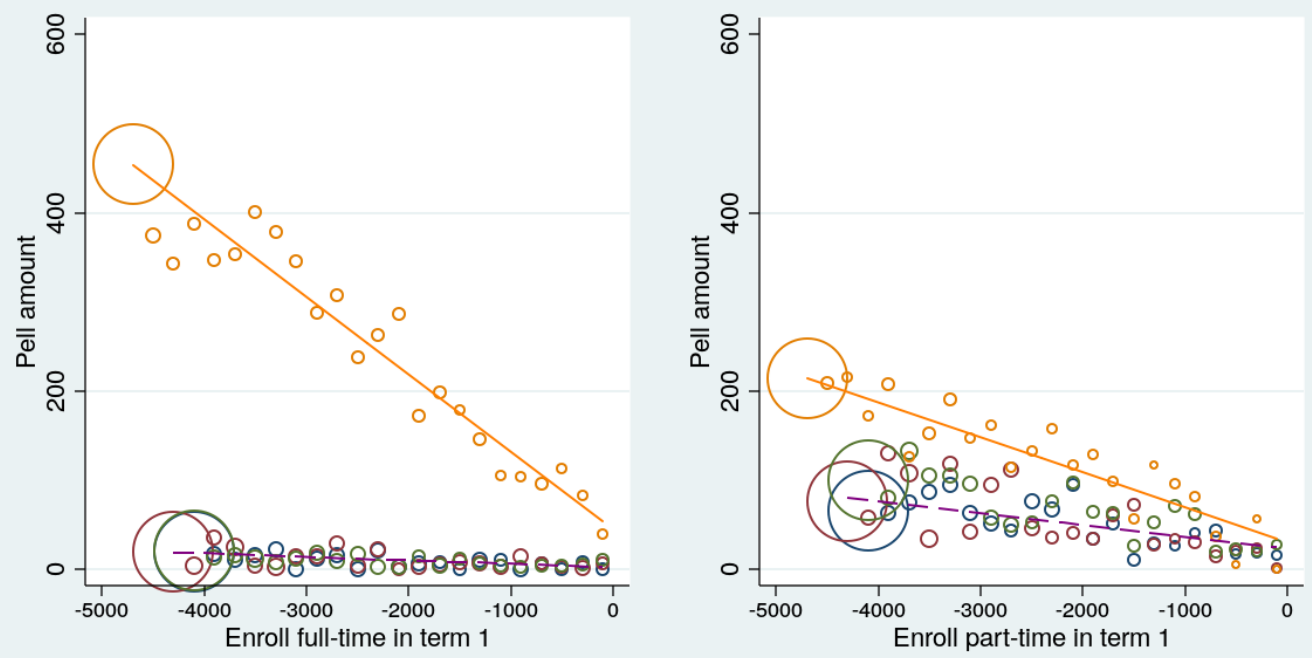

\begin{tabular}{|c|c|c|c|}
\hline 0 & 2006 & 0 & 2007 \\
\hline$\circ$ & 2008 & ० & 2009 \\
\hline---- & 2007 & & 2009 \\
\hline
\end{tabular}

Distance from Pell Grant Eligibility Threshold

B. Total Pell amount in Fall and Spring
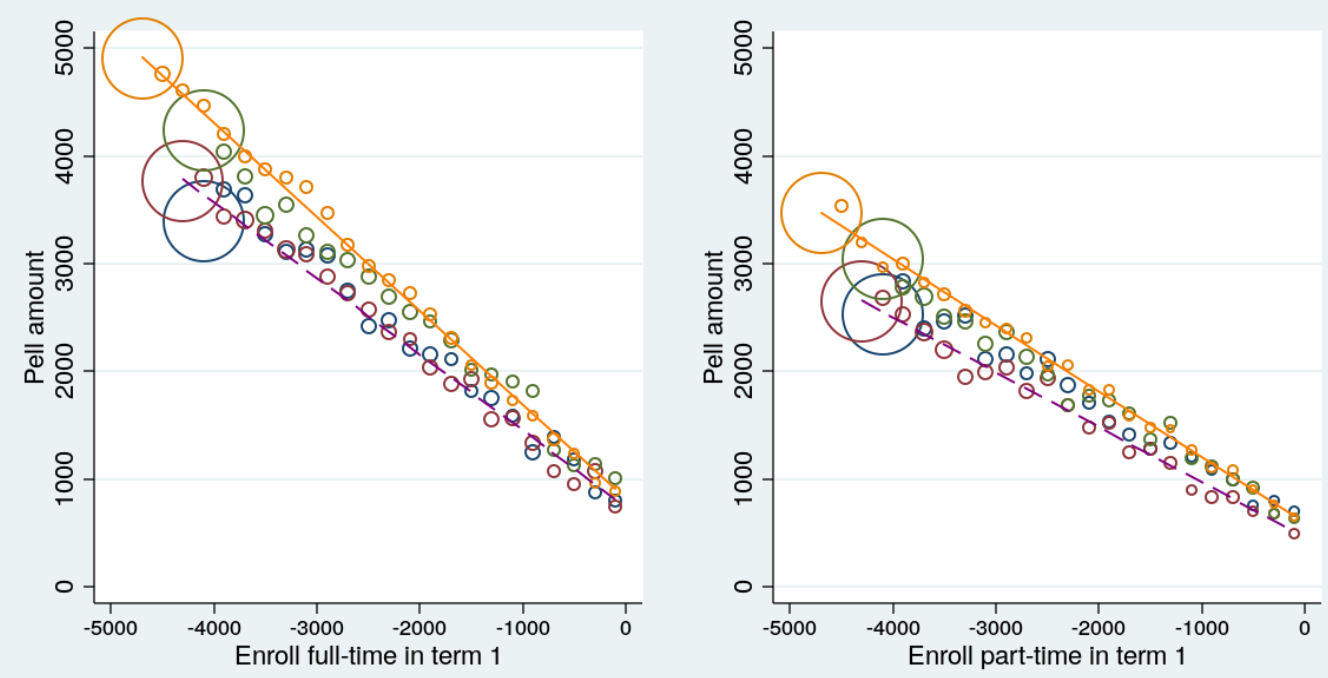

\begin{tabular}{|crrrr|}
\hline$\circ$ & 2006 & $\circ$ & 2007 \\
$\circ$ & 2008 & $\circ$ & 2009 \\
---- & 2007 & & & 2009 \\
\hline
\end{tabular}

Distance from Pell Grant Eligibility Threshold 
Figure 2

\section{Student Characteristics by Cohort}

A. Zero EFC

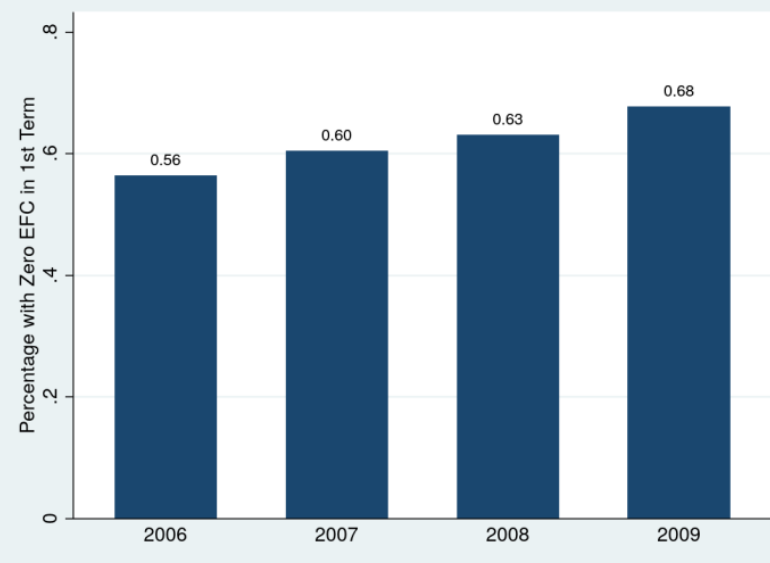

B. Expected Family Contribution in First Term

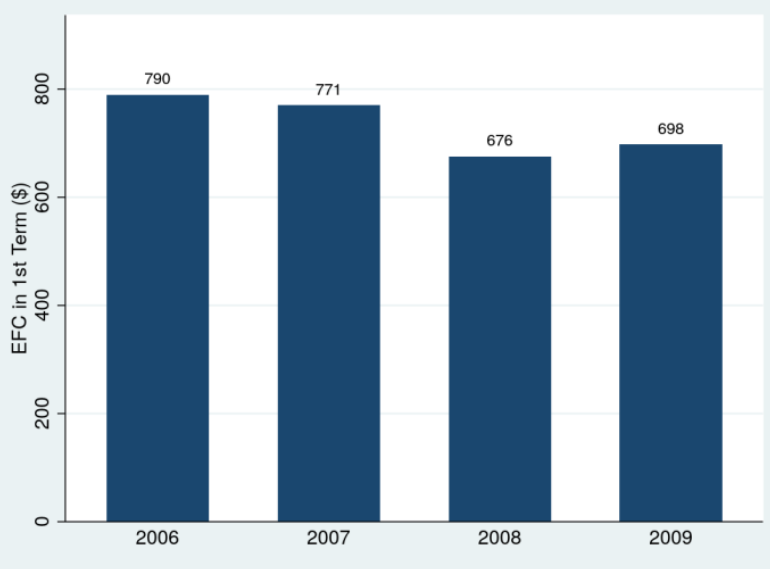

D. Full-Time Status
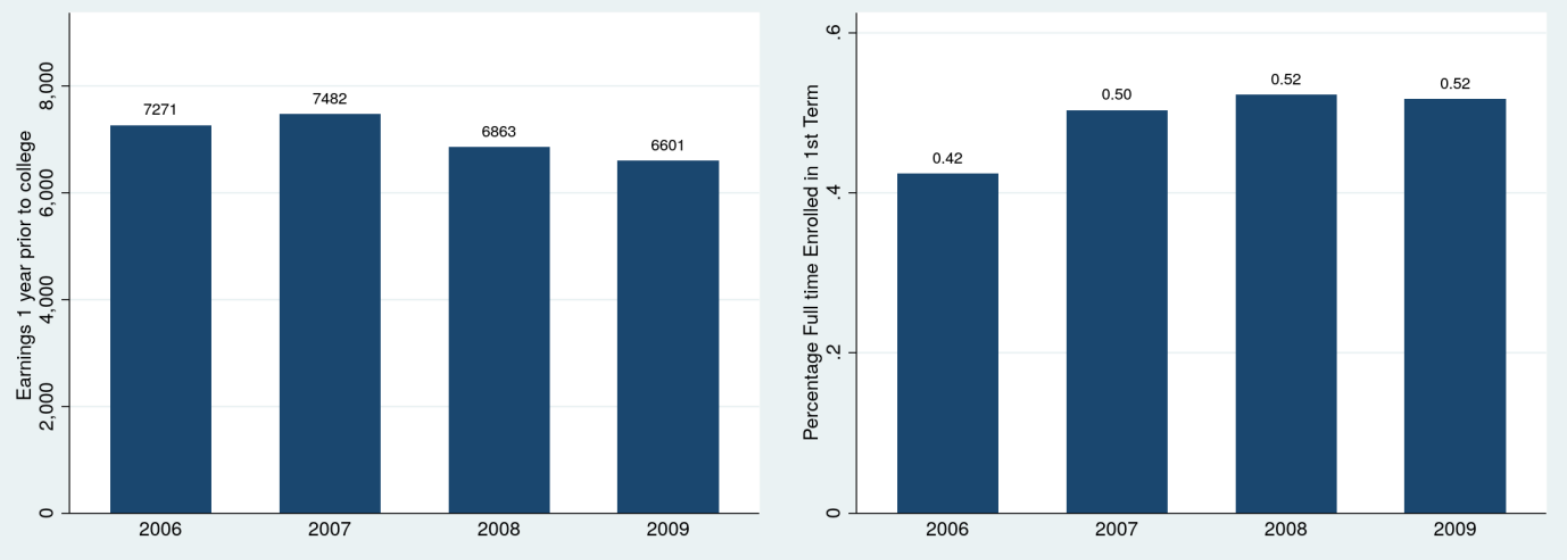

E. Credits Earned in First Term

F. GPA Earned in First Term

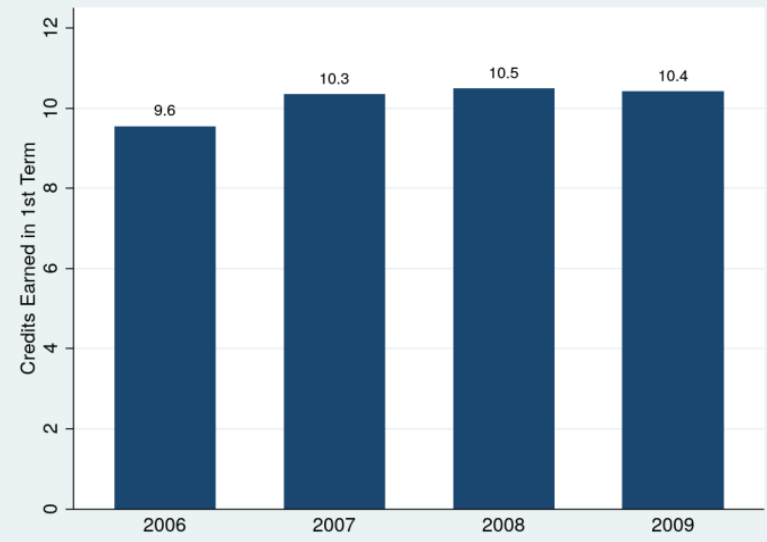

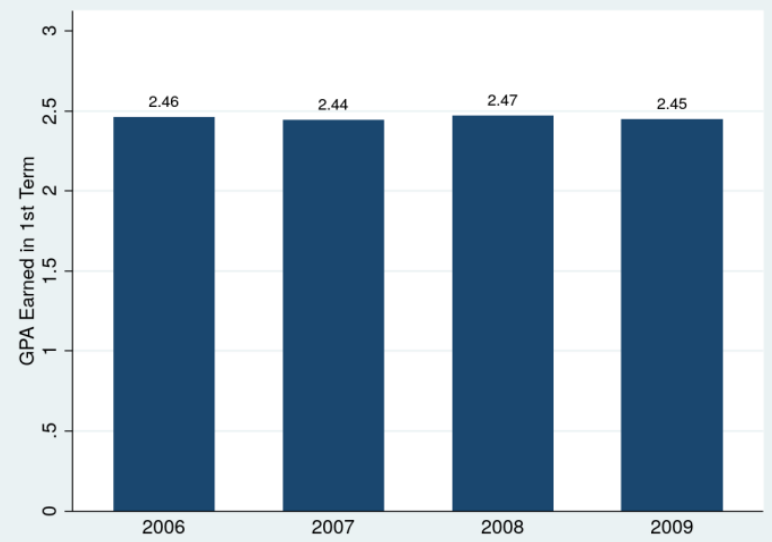


Table 2

Credits Earned and Pell Amount of YRP Recipients

\begin{tabular}{lc}
\hline & $\begin{array}{c}\text { Credits Earned/ } \\
\text { Pell Amount }\end{array}$ \\
\hline Observations & 1,044 \\
Credits earned term 1 & 14.1 \\
Credits earned term 2 & 14.5 \\
Credits earned term 3 & 8.0 \\
Credits enrolled first summer & 8.4 \\
Earned over 6 credits in summer & $71 \%$ \\
Pell amount in term 1 & $\$ 2,315$ \\
Pell amount in term 2 & $\$ 2,320$ \\
Pell amount in term 3 & $\$ 1,529$ \\
\hline
\end{tabular}

As discussed above, one of the key assumptions of the model is that creditsmoothing does not occur. If credit-smoothing occurs, than the YRP may not have a meaningful academic effect. Specifically, the YRP may encourage students that would have taken more than a full-time load to adjust their credit-taking pattern to benefit financially from the YRP without increasing their credits enrolled for the entire year. Figure 3 shows the distribution of the total credits enrolled in during the first term for students starting between 2006 and 2009. It rules out the possibility of credit-smoothing as the distributions are similar across all years.

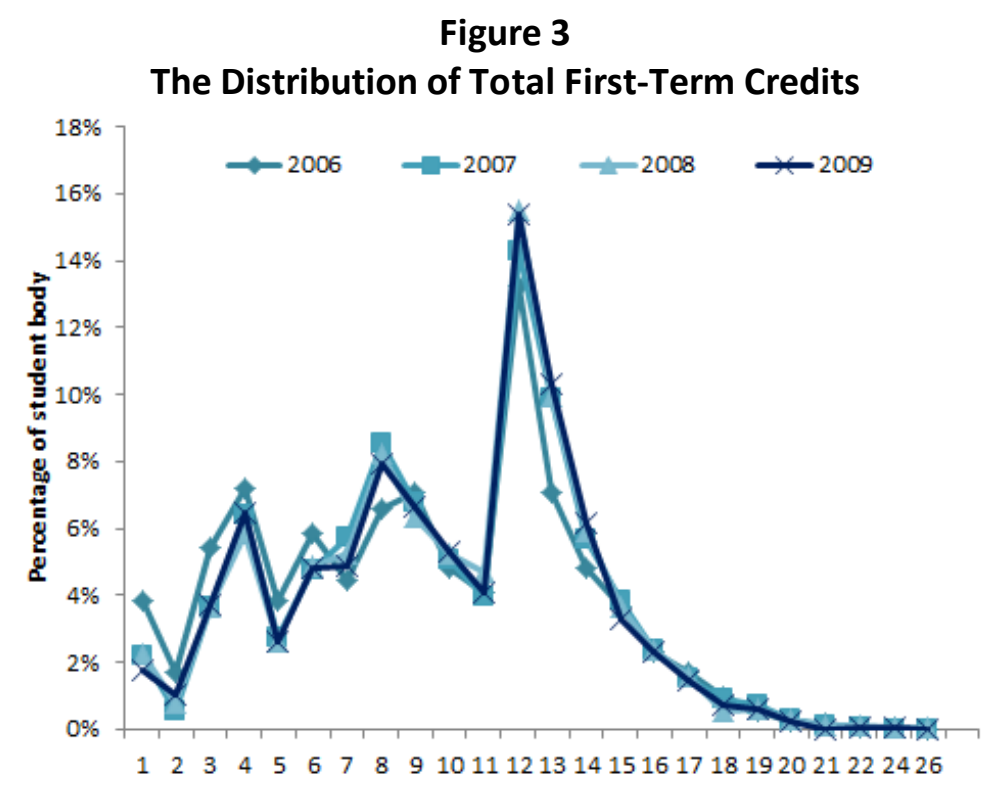




\section{Estimation Strategy}

\subsection{Difference-in-Difference Model}

To examine the effect of the YRP on student outcomes, this paper follows previous research by using a difference-in-difference strategy to compare the differences in the outcomes of full-time and part-time students enrolling before and after the YRP implementation. The key equation is:

$$
Y_{i}=\alpha+\gamma \text { Post }_{i}+\delta \text { Treat }_{i}+\beta\left(\text { Post }_{i} * \text { Treat }_{i}\right)+\sigma X_{i}+\varepsilon_{i}
$$

where $Y_{i}$ is the outcome of interest, such as enrollment and credits earned in the summer, completion rates, financial aid, employment rates, and earnings in subsequent terms and years.

Post $_{i}$ is a binary variable which equals to 1 if individual $i$ enrolls in college for the first time after the implementation of the YRP. It estimates the general cohort effect of enrolling after the summer of 2008. Treat $_{i}$ equals 1 if an individual attends college full-time in the first semester. Since students must enroll in at least 24 credits in the fall and spring semesters to be eligible for the YRP, enrolling part-time in the first semester makes it very difficult to receive the YRP. Though students can enroll in a more than full-time credit load in the second semester, only five percent of the YRP recipients are part-time in their first term. This variable essentially also captures any systematic differences in outcomes between full-time and part-time students. Post $_{i} *$ Treat $_{i}$ is the interaction between Post $_{i}$ and Treat ${ }_{i}$, which captures the effect of the YRP.

$X_{i}$ is a vector of demographic characteristics, such as race/ethnicity, gender, high school graduation status, GPA, credits earned in the first term, expected family contribution, and Pell Grant disbursement in the first term, college, and major fixed effects. Years of work experience and its squared term are also controls for any regression with employment outcomes.

\subsection{Evaluation of the DID Assumptions}

I address two concerns that may potentially violate the parallel trend assumption required for DID analysis. First, the recession in 2008 may have changed the composition 
of the cohort enrolling in the fall of 2009, making it unsuitable for comparison with the prior cohorts. The Post $_{i}$ variable captures some of the cohort-specific effects. Controlling for first semester financial aid and academic information in all regressions also removes effects that are attributed to socioeconomic status or ability. Figure 2 also confirms that the student composition of the 2009 cohort is similar to prior cohorts in terms of the percentage of students with zero EFC, EFC in the first term (fall), earnings one year prior to enrollment, percentage with full-time status, credits earned in the first term, and GPA in the first term.

Second, the recession may also have influenced the composition of full-time or part-time students in different ways. Reassuringly, Panel D of Figure 2 shows that the percentage of full-time students remains at 52 percent between 2008 and 2009. Figure 4 also shows that the composition of these two groups of students is comparable across years in terms of the percentage of minority students and the percentage who graduated from high school. The EFC of part-time students enrolled in 2009 looks slightly lower than that of previous cohorts. Yet the differences do not affect the credits earned in the fall and spring terms. As expected, the credits earned in the summer spike with the fulltime students enrolled in 2009 and not with part-time students or students enrolled before 2009.

I also conducted subgroup analysis of students in the sample who have intent to enroll in a certificate or diploma program. These students are likely to have different goals and responses to the YRP than students enrolled in an associate degree program. They face lower credit requirements and may therefore be more incentivized by the YRP to graduate faster. Figure 5 confirms that the percentages of students with the intent to enroll in certificate programs are similar across cohorts and across students with different enrollment statuses. Similar to the full sample, the student composition is stable across cohorts for all characteristics with the slight exception of the percentage of students with zero EFC. The percentage of students intending to enroll in associate degree programs with zero EFC increases slightly over time.

Section 6 (Results) below also provides event study plots to evaluate the year-byyear trend for a set of outcomes adjusted for the year trend, full-time or part-time trend, and other covariates. 
Figure 4

\section{Student Characteristics by Cohort and Full-Time/Part-Time Status}
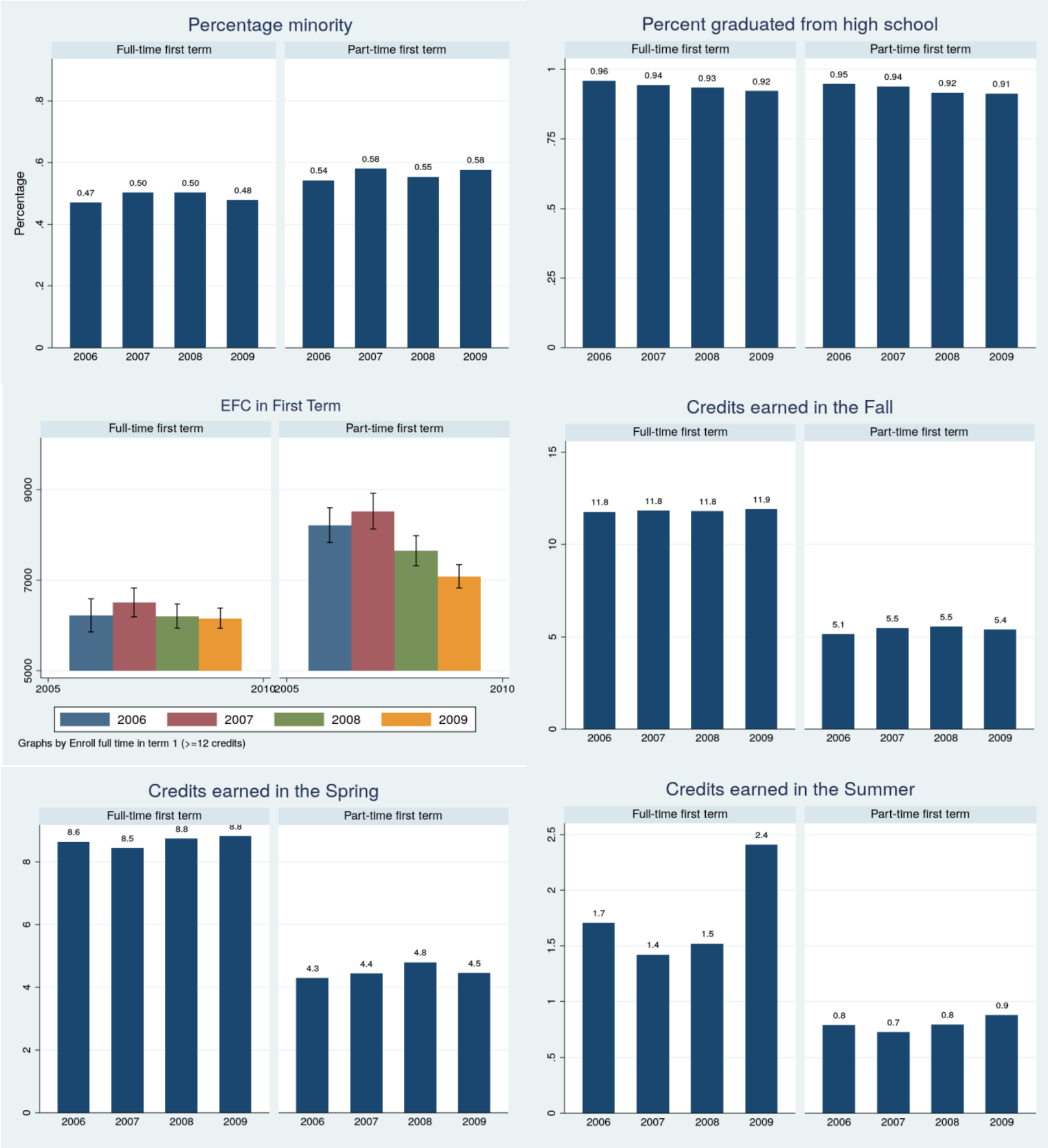
Figure 5

Student Characteristics of Students Enrolled in Certificate Programs
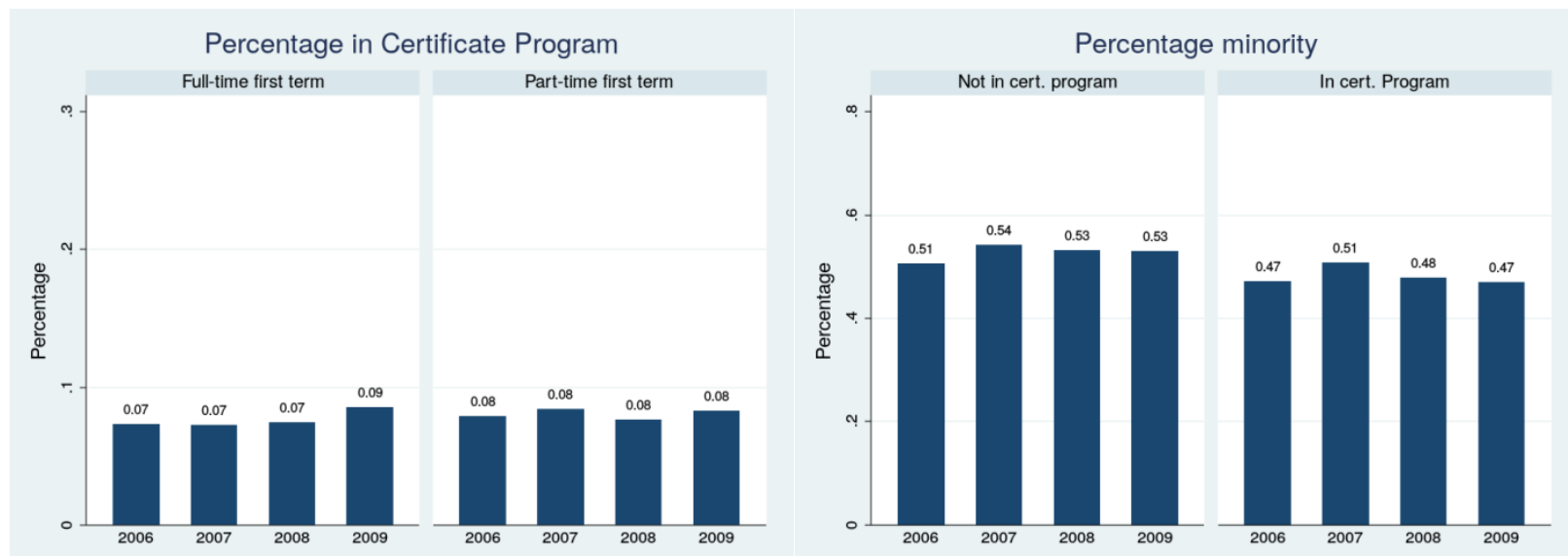

Percentage graduated from high school
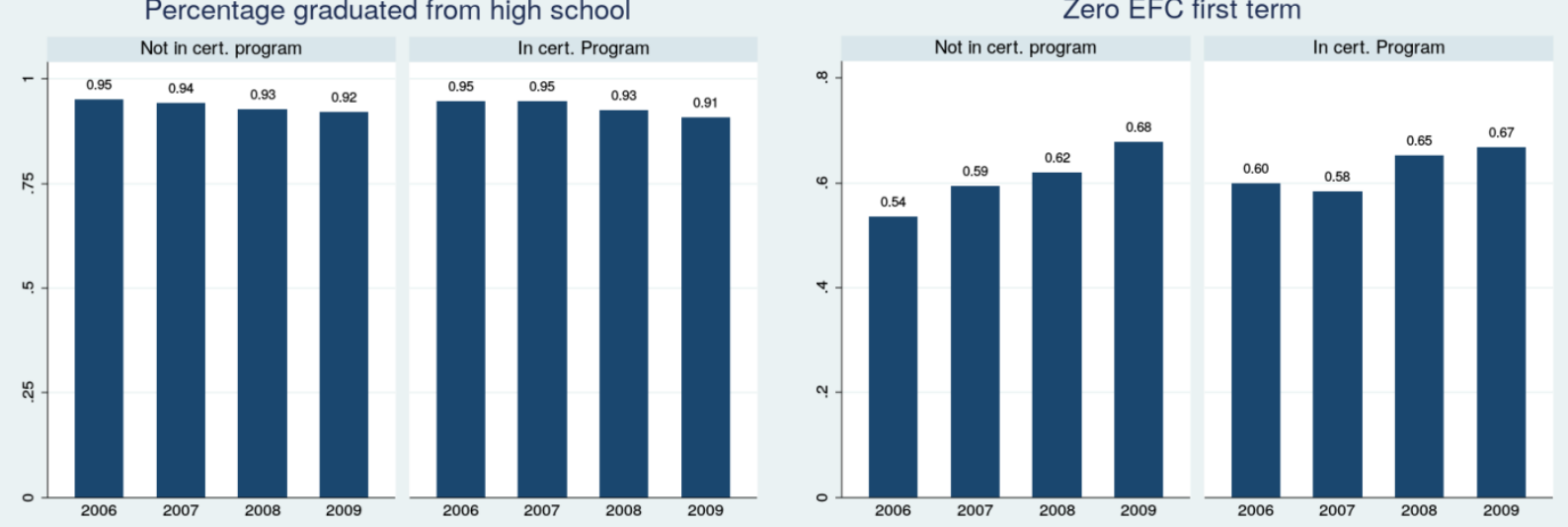

Credits Earned in 1st Term

Credits Earned in 2nd Term
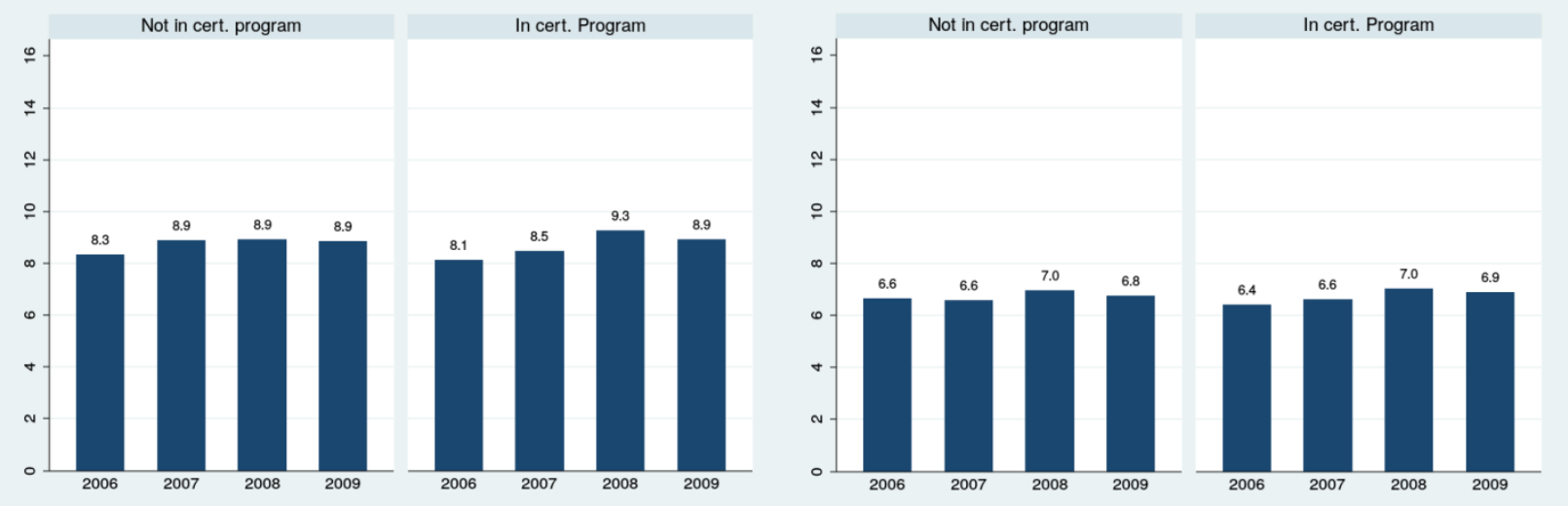


\section{Results}

\subsection{Summer Enrollment}

Table 3 shows estimates of the effect of YRP eligibility on academic outcomes of the first summer terms. Each row is for a separate regression and shows the coefficient of the interaction term between Post $_{i}$ and Treat ${ }_{i}$. Panels 1-4 test whether the introduction of the YRP affects the Pell disbursements and summer course-taking patterns among eligible students. Without controlling for any other variables, the estimated effects of YRP eligibility are \$321 per student for the whole sample and \$488 per student for those enrolled in certificate programs. The estimates remain stable after adding covariates.

In panels 2 and 3, the DID estimates of the effect of YRP eligibility on the probability of summer enrollment and credits earned are 8.3 percentage points and 0.7 credits per student respectively when including covariates. Panel 4 measures the impact of YRP eligibility on summer enrollment in an alternative way. One of the eligibility requirements for the YRP is that students must be enrolled in 6 credits in the summer. Panel 4 indicates that eligible students are 5.5 percentage points more likely to have earned over 6 credits in the summer.

Consistent with the idea that students in certificate and diploma programs may be more incentivized by the YRP to graduate faster (see Section 5.2 above), the estimates on summer outcomes (panels 2-4) for students enrolled in certificate or diploma programs are generally twice as high as those for the whole sample. 
Table 3

DID Estimates of the Effect of YRP Eligibility on Academic Outcomes in the First Summer

\begin{tabular}{|c|c|c|c|c|c|}
\hline Outcomes & Post*Full-Time & SE & $N$ & $\begin{array}{c}\text { Include } \\
\text { Covariates }\end{array}$ & $\begin{array}{l}\text { Enrolled in Short-Term } \\
\text { Programs }\end{array}$ \\
\hline \multirow[t]{4}{*}{ 1. Pell amount in summer } & $321 * * *$ & [13] & 26,598 & & \\
\hline & $312 * * *$ & [13] & 26,598 & $x$ & \\
\hline & $488 * * *$ & {$[48]$} & 2,632 & & $x$ \\
\hline & $469 * * *$ & {$[46]$} & 2,632 & $x$ & $x$ \\
\hline \multirow[t]{4}{*}{ 2. Took class in Summer } & $0.093 * * *$ & [0.010] & 26,598 & & \\
\hline & $0.083^{* * *}$ & {$[0.010]$} & 26,598 & $x$ & \\
\hline & $0.164 * * *$ & [0.034] & 2,632 & & $x$ \\
\hline & $0.144 * * *$ & [0.032] & 2,632 & $x$ & $x$ \\
\hline \multirow[t]{4}{*}{ 3. Credits earned in summer } & $0.768 * * *$ & [0.074] & 26,598 & & \\
\hline & $0.698 * * *$ & [0.069] & 26,598 & $x$ & \\
\hline & $1.393^{* * *}$ & {$[0.265]$} & 2,632 & & $x$ \\
\hline & $1.287^{* * *}$ & {$[0.253]$} & 2,632 & $x$ & $x$ \\
\hline \multirow[t]{4}{*}{ 4.Earned over six credits in summer } & $0.060 * * *$ & [0.007] & 26,598 & & \\
\hline & $0.055^{* * *}$ & {$[0.007]$} & 26,598 & $x$ & \\
\hline & $0.117^{* * *}$ & {$[0.026]$} & 2,632 & & $x$ \\
\hline & $0.115^{* * *}$ & {$[0.025]$} & 2,632 & $x$ & $x$ \\
\hline
\end{tabular}

Note. Each row is for a separate regression. Coefficients are for the interaction of post-2008 indicator variable with full-time enrollment status in the first term. Robust standard errors are in brackets. All specifications include post-2008 indicator variable and full-time enrollment status in the first term. The regressions with covariates control for race/ethnicity, gender, high school graduation status, grade point average and credits earned in the first term, expected family contribution, and Pell Grant amount in the first term, intent at college entry, and college and major fixed effects. Credits earned in the first term is not included as a covariate when it is the outcome variable.

$* * * p<.01, * * p<.05, * p<.1$.

\subsection{Credits Earned and Degree Completion}

To explore whether students engage in credit-smoothing behavior as a result of the YRP, panels 1 and 2 of Table 4 display the estimates on credits earned in each semester and find no evidence for any smoothing behavior.

Panels 3-5 estimate the impact of the YRP on completion rates. The DID estimate for certificate attainment is 0.3 percent and not statistically significant using the entire sample, yet it is 3 percent and statistically significant for students with an intention to earn a certificate.

There is no impact on diploma completion rates, but the completion rate for associate degrees is 0.7 percentage points higher among those eligible for the YRP.

It is important to point out that the majority of certificate holders have excess credits or credits that do not count toward their credential. On average, certificate holders earned 21 credits in the first year, which is more than the 12 to 18 credits required for 
certificate programs. This finding suggests that increasing academic advisement to students in these programs could facilitate more efficient use of federal funding and students’ resources.

Table 4

DID Estimates of the Effect of YRP Eligibility on Academic Outcomes of the First 3 Years

\begin{tabular}{|c|c|c|c|c|c|}
\hline Outcomes & Post*Full-Time & SE & $N$ & $\begin{array}{c}\text { Include } \\
\text { Covariates } \\
\end{array}$ & $\begin{array}{c}\text { Enrolled in Short-Term } \\
\text { Programs } \\
\end{array}$ \\
\hline \multirow[t]{4}{*}{ 1.Credits earned in fall } & 0.101 & [0.092] & 26,598 & & \\
\hline & -0.003 & [0.089] & 26,598 & $x$ & \\
\hline & -0.098 & [0.317] & 2,632 & & $x$ \\
\hline & -0.134 & [0.312] & 2,632 & $x$ & $x$ \\
\hline \multirow[t]{4}{*}{ 2. Credits earned in the spring } & $0.278 * *$ & {$[0.134]$} & 26,598 & & \\
\hline & 0.029 & [0.116] & 26,598 & $x$ & \\
\hline & 0.141 & [0.458] & 2,632 & & $x$ \\
\hline & -0.084 & [0.407] & 2,632 & $x$ & $x$ \\
\hline \multirow[t]{4}{*}{ 3. Earned certificate in one year } & $0.005^{*}$ & [0.003] & 26,598 & & \\
\hline & 0.003 & [0.003] & 26,598 & $x$ & \\
\hline & $0.032 * *$ & [0.015] & 2,632 & & $x$ \\
\hline & $0.034^{* *}$ & [0.015] & 2,632 & $x$ & $x$ \\
\hline \multirow[t]{4}{*}{ 4. Earned diploma in 2.5 years } & $0.006 *$ & [0.003] & 26,598 & & \\
\hline & 0.005 & [0.003] & 26,598 & $x$ & \\
\hline & -0.011 & {$[0.011]$} & 2,632 & & $x$ \\
\hline & -0.011 & [0.011] & 2,632 & $\mathrm{x}$ & $x$ \\
\hline \multirow[t]{4}{*}{ 5. Earned associate degree in 2.5 years } & $0.011^{* * *}$ & [0.004] & 26,598 & & \\
\hline & $0.007^{*}$ & [0.004] & 26,598 & $x$ & \\
\hline & 0.011 & [0.012] & 2,632 & & $x$ \\
\hline & 0.010 & [0.013] & 2,632 & $x$ & $x$ \\
\hline
\end{tabular}

Note. Each row is for a separate regression. Coefficients are for the interaction of post-2008 indicator variable with full-time enrollment status in the first term. Robust standard errors are in brackets. All specifications include post-2008 indicator variable and full-time enrollment status in the first term. The regressions with covariates control for race/ethnicity, gender, high school graduation status, grade point average and credits earned in the first term, expected family contribution, and Pell Grant amount in the first term, intent at college entry, and college and major fixed effects. Credits earned in the first term is not included as a covariate when it is the outcome variable.

$* * * p<.01, * * p<.05, * p<.1$.

\subsection{Financial Aid}

Table 5 shows the effect of the YRP on various financial aid outcomes. Recent literature suggests that a more generous grant may have a crowding-out effect on other financial aid. Marx and Turner (2017) found an over 100 percent reduction in loans as a result of increased Pell disbursements within \$1,000 of the Pell Grant eligibility threshold 
when there is a fixed cost in borrowing. The amount of the YRP is relatively small; panels 1-3 show that it has no impact on loan patterns.

Table 5

DID Estimates of the Effect of YRP on Financial Aid Outcomes

\begin{tabular}{|c|c|c|c|c|c|}
\hline Outcomes & Post*Full-Time (\$) & SE & $N$ & $\begin{array}{c}\text { Include } \\
\text { Covariates }\end{array}$ & $\begin{array}{c}\text { Enrolled in } \\
\text { Short-Term } \\
\text { Programs }\end{array}$ \\
\hline \multirow[t]{4}{*}{ 1. Loan in the fall } & 19 & {$[16]$} & 26,598 & & \\
\hline & 7 & {$[15]$} & 26,598 & $x$ & \\
\hline & -24 & [49] & 2,632 & & $x$ \\
\hline & -27 & {$[48]$} & 2,632 & $\mathrm{x}$ & $x$ \\
\hline \multirow[t]{4}{*}{ 2. Loan in the spring } & $37 * *$ & {$[18]$} & 26,598 & & \\
\hline & 23 & [17] & 26,598 & $x$ & \\
\hline & -75 & [59] & 2,632 & & $x$ \\
\hline & -69 & [57] & 2,632 & $x$ & $x$ \\
\hline \multirow[t]{4}{*}{ 3. Loan in the summer } & -1 & [7] & 26,598 & & \\
\hline & -3 & [7] & 26,598 & $x$ & \\
\hline & 4 & [24] & 2,632 & & $x$ \\
\hline & 13 & {$[24]$} & 2,632 & $\mathrm{x}$ & $x$ \\
\hline \multirow[t]{4}{*}{ 4. Other aid in the fall (non-Pell or loan) } & $64 * * *$ & [18] & 26,598 & & \\
\hline & $71^{* * *}$ & [17] & 26,598 & $x$ & \\
\hline & 36 & [46] & 2,632 & & $x$ \\
\hline & 37 & {$[42]$} & 2,632 & $x$ & $x$ \\
\hline \multirow[t]{4}{*}{ 5.Other aid in the spring (non-Pell or loan) } & $-145^{* * *}$ & {$[12]$} & 26,598 & & \\
\hline & $-142 * * *$ & {$[11]$} & 26,598 & $x$ & \\
\hline & $-116 * * *$ & [37] & 2,632 & & $x$ \\
\hline & $-121 * * *$ & {$[36]$} & 2,632 & $x$ & $x$ \\
\hline \multirow[t]{4}{*}{ 6. Other aid in the summer (non-Pell or loan) } & $-4 * *$ & {$[2]$} & 26,598 & & \\
\hline & $-6 * * *$ & {$[2]$} & 26,598 & $x$ & \\
\hline & -5 & [7] & 2,632 & & $x$ \\
\hline & -7 & [7] & 2,632 & $x$ & $x$ \\
\hline
\end{tabular}

Note. Each row is for a separate regression. Coefficients are for the interaction of post-2008 indicator variable with full-time enrollment status in the first term. Robust standard errors are in brackets. All specifications include post-2008 indicator variable and full-time enrollment status in the first term. The regressions with covariates control for race/ethnicity, gender, high school graduation status, grade point average and credits earned in the first term, expected family contribution, and Pell Grant amount in the first term, intent at college entry, and college and major fixed effects.

$* * * \mathrm{p}<.01, * * \mathrm{p}<.05, * \mathrm{p}<.1$. 
Turner (2014) found that institutions may try to capture the increase in the federal grant by reducing institutional aid. Panels 4-6 show that the estimates for other aid, excluding the federal Pell Grants or loans, are positive in the fall semester and negative in the spring semester. Overall, the net effect on state and institutional aid-which is the sum of the coefficients over fall (\$71), spring (-\$142), and summer terms (-\$6) —is about $-\$ 77$, or 25 percent, of the gains in the YRP (\$312) for the first year for the whole sample and $-\$ 121$ for students with intent to complete a certificate. Accordingly, these results show some evidence of the crowding-out effect.

\subsection{Labor Market Outcomes}

The last set of outcomes concerns the probability of employment and earnings during and after enrollment up to three years from college entry. Tables 1 and 2 show that YRP eligible students and YRP recipients on average take 8.4 credits in the summer. In anticipation of less time for employment during the summer, some YRP eligible students may increase employment during the academic year. The impact should be minimal given that the additional course load is small. Table 6 indicates that the probability of employment is 3.7 percentage points higher with an average increase in earnings of \$146 in the fall for the full sample. Otherwise, no employment impact is found in the spring or the summer terms.

Panels 1-3 of Table 7 present the DID estimates of the impact of YRP eligibility on the probability of employment in the first three years from college entry. There are no statistically significant impacts of YRP eligibility on these outcomes.

Most students are still in school during the first two years from college entry. As a result, the introduction of the YRP also does not seem to influence the earnings of YRP eligible students in the first two years. Yet panel 6 indicates that the YRP induces an increase in earnings in the third year from college entry of $\$ 681$ for the entire sample and $\$ 1,390$ for those in certificate programs. These results suggest that the YRP may be beneficial not only for individuals but for society as a whole through an increase in federal and state tax revenue. 
Table 6

DID Estimates of the Effect of YRP Eligibility on Labor Market Outcomes in the First Year

\begin{tabular}{|c|c|c|c|c|c|}
\hline Outcomes & Post*Full-Time & SE & $N$ & $\begin{array}{l}\text { Include } \\
\text { Covariates }\end{array}$ & $\begin{array}{l}\text { Enrolled in Short- } \\
\text { Term Programs }\end{array}$ \\
\hline \multirow[t]{4}{*}{ 1. Employed in the fall } & $0.024 *$ & [0.012] & 26,598 & & \\
\hline & $0.037 * * *$ & [0.012] & 26,598 & $x$ & \\
\hline & 0.029 & {$[0.040]$} & 2,632 & & $x$ \\
\hline & 0.044 & [0.040] & 2,632 & $x$ & $x$ \\
\hline \multirow[t]{4}{*}{ 2. Employed in the spring } & -0.003 & [0.012] & 26,598 & & \\
\hline & 0.009 & [0.012] & 26,598 & $x$ & \\
\hline & -0.035 & {$[0.040]$} & 2,632 & & $x$ \\
\hline & -0.035 & {$[0.040]$} & 2,632 & $x$ & $x$ \\
\hline \multirow[t]{4}{*}{ 3. Employed in the summer } & $-0.021 *$ & [0.012] & 26,598 & & \\
\hline & -0.010 & [0.012] & 26,598 & $x$ & \\
\hline & -0.026 & [0.041] & 2,632 & & $x$ \\
\hline & -0.023 & [0.040] & 2,632 & $x$ & $x$ \\
\hline \multirow[t]{4}{*}{ 7. Earnings in the fall } & $97^{*}$ & {$[56]$} & 26,598 & & \\
\hline & $146 * * *$ & {$[55]$} & 26,598 & $x$ & \\
\hline & 162 & [197] & 2,632 & & $x$ \\
\hline & 152 & [196] & 2,632 & $x$ & $x$ \\
\hline \multirow[t]{4}{*}{ 8. Earnings in the spring } & 26 & [103] & 26,598 & & \\
\hline & 96 & [100] & 26,598 & $x$ & \\
\hline & 135 & [383] & 2,632 & & $x$ \\
\hline & 115 & [387] & 2,632 & $x$ & $x$ \\
\hline \multirow[t]{4}{*}{ 9. Earnings in the summer } & -35 & {$[60]$} & 26,598 & & \\
\hline & -7 & [59] & 26,598 & $x$ & \\
\hline & 198 & [233] & 2,632 & & $x$ \\
\hline & 121 & [231] & 2,632 & $x$ & $x$ \\
\hline
\end{tabular}

Note. Each row is for a separate regression. Coefficients are for the interaction of post-2008 indicator variable with full-time enrollment status in the first term. Robust standard errors are in brackets. All specifications include post2008 indicator variable and full-time enrollment status in the first term. The regressions with covariates control for year of work experience and its squared term, race/ethnicity, gender, high school graduation status, grade point average and credits earned in the first term, expected family contribution and Pell grant amount in the first term, intent at college entry, and college and major fixed effects.

$* * * p<.01, * * p<.05, * p<.1$. 
Table 7

DID Estimates of the Effect of YRP Eligibility on Labor Market Outcomes in the First Three Years

\begin{tabular}{|c|c|c|c|c|c|}
\hline Outcomes & Post*Full-Time & SE & $N$ & $\begin{array}{c}\text { Include } \\
\text { Covariates }\end{array}$ & $\begin{array}{l}\text { Enrolled in Short- } \\
\text { Term Programs }\end{array}$ \\
\hline \multirow[t]{4}{*}{ 1. Employed in the first year } & -0.000 & [0.012] & 26,598 & & \\
\hline & 0.010 & {$[0.011]$} & 26,598 & $x$ & \\
\hline & -0.011 & [0.039] & 2,632 & & $\mathrm{x}$ \\
\hline & -0.007 & [0.039] & 2,632 & $x$ & $x$ \\
\hline \multirow[t]{4}{*}{ 2. Employed in the second year } & -0.002 & {$[0.011]$} & 26,598 & & \\
\hline & 0.007 & {$[0.011]$} & 26,598 & $x$ & \\
\hline & 0.007 & [0.038] & 2,632 & & $x$ \\
\hline & 0.008 & {$[0.037]$} & 2,632 & $x$ & $x$ \\
\hline \multirow[t]{4}{*}{ 3. Employed in the third year } & -0.001 & [0.012] & 26,598 & & \\
\hline & 0.009 & {$[0.011]$} & 26,598 & $x$ & \\
\hline & -0.022 & [0.038] & 2,632 & & $x$ \\
\hline & -0.018 & {$[0.037]$} & 2,632 & $x$ & $x$ \\
\hline \multirow[t]{4}{*}{ 4. Earnings in the first year } & 80 & [201] & 26,598 & & \\
\hline & 227 & [195] & 26,598 & $x$ & \\
\hline & 486 & [739] & 2,632 & & $x$ \\
\hline & 375 & [738] & 2,632 & $x$ & $x$ \\
\hline \multirow[t]{4}{*}{ 5. Earnings in the second year } & 310 & [263] & 26,598 & & \\
\hline & 407 & [265] & 26,598 & $x$ & \\
\hline & 1,172 & [990] & 2,632 & & $x$ \\
\hline & 953 & [959] & 2,632 & $x$ & $x$ \\
\hline \multirow[t]{4}{*}{ 6. Earnings in the third year } & $609 * * *$ & [184] & 26,598 & & \\
\hline & $681 * * *$ & [179] & 26,598 & $x$ & \\
\hline & $1,433^{* *}$ & [648] & 2,632 & & $x$ \\
\hline & $1,390 * *$ & [637] & 2,632 & $x$ & $x$ \\
\hline
\end{tabular}

Note. Each row is for a separate regression. Coefficients are for the interaction of post-2008 indicator variable with full-time enrollment status in the first term. Robust standard errors are in brackets. All specifications include post-2008 indicator variable and full-time enrollment status in the first term. The regressions with covariates control for year of work experience and its squared term, race/ethnicity, gender, high school graduation status, grade point average and credits earned in the first term, expected family contribution and Pell grant amount in the first term, intent at college entry, and college and major fixed effects.

${ }^{* * *} \mathrm{p}<.01,{ }^{* *} \mathrm{p}<.05,{ }^{*} \mathrm{p}<.1$ 


\subsection{Subgroup Analysis}

Table 8 shows a set of key estimates on academic and employment outcomes by gender and by whether students were enrolled in a certificate program. The results are generally consistent with Tables 3 to 7, with some variations by gender. The DID estimates are positive and statistically significant in the first summer for both women and men. All gains in certificate and diploma completion rates accrue to women. YRP eligible women who enrolled in a certificate program are 5.8 percentage points more likely to receive a certificate within one year, and YRP eligible women are 0.8 percentage points more likely to earn a diploma. The gain in associate degree completion rates, however, is concentrated among men. YRP eligible men are 1.2 percentage points more likely to have completed an associate degree in 2.5 years.

The YRP seems to induce more YRP eligible women to work in the first term, yet YRP eligible men tend to earn more on average in that term. In the third year of college enrollment, YRP eligible students of both genders experience similar earnings gains.

Table 9 examines the same set of outcomes by the age of enrollment. Pell Grants may have a different impact on the group of students who enroll within two years of high school graduation versus those attend later (Seftor \& Turner, 2002). The DID estimates on the amount of YRP received and credits earned in the first summer are higher for older students. The gains in completion rates and earnings are concentrated among older students. These findings are consistent with the research previously mentioned that investigated the effect of Pell Grants on adult student outcomes. 


\section{Table 8}

DID Estimates of the Effect of YRP Eligibility by Gender

\begin{tabular}{|c|c|c|c|c|c|}
\hline Outcomes & Post*Full-Time & SE & $N$ & Subgroup & $\begin{array}{l}\text { Enrolled in Short- } \\
\text { Term Programs }\end{array}$ \\
\hline \multirow[t]{4}{*}{ 1. Pell amount in summer } & $291^{* * *}$ & [16] & 18,015 & Women & \\
\hline & $349 * * *$ & {$[21]$} & 8,583 & Men & \\
\hline & $456 * * *$ & {$[65]$} & 1,518 & Women & $x$ \\
\hline & $444 * * *$ & {$[67]$} & 1,114 & Men & $x$ \\
\hline \multirow[t]{4}{*}{ 2. Credits earned in summer } & $0.706 * * *$ & {$[0.084]$} & 18,015 & Women & \\
\hline & $0.630 * * *$ & [0.120] & 8,583 & Men & \\
\hline & $1.598 * * *$ & {$[0.354]$} & 1,518 & Women & $x$ \\
\hline & $0.704 *$ & [0.374] & 1,114 & Men & $x$ \\
\hline \multirow[t]{4}{*}{ 3. Earned certificate in one year } & 0.004 & [0.003] & 18,015 & Women & \\
\hline & 0.003 & [0.007] & 8,583 & Men & \\
\hline & $0.058 * * *$ & {$[0.020]$} & 1,518 & Women & $x$ \\
\hline & -0.005 & [0.023] & 1,114 & Men & $x$ \\
\hline \multirow[t]{4}{*}{ 4. Earned diploma in 2.5 years } & $0.008^{* *}$ & {$[0.004]$} & 18,015 & Women & \\
\hline & -0.001 & {$[0.006]$} & 8,583 & Men & \\
\hline & 0.005 & {$[0.014]$} & 1,518 & Women & $x$ \\
\hline & -0.024 & {$[0.018]$} & 1,114 & Men & $x$ \\
\hline \multirow[t]{4}{*}{ 5. Earned associate degree in 2.5 years } & 0.003 & {$[0.004]$} & 18,015 & Women & \\
\hline & $0.012^{*}$ & {$[0.007]$} & 8,583 & Men & \\
\hline & 0.017 & {$[0.017]$} & 1,518 & Women & $x$ \\
\hline & -0.006 & {$[0.020]$} & 1,114 & Men & $x$ \\
\hline \multirow[t]{4}{*}{ 5. Employed in the fall } & $0.043^{* * *}$ & [0.015] & 18,015 & Women & \\
\hline & 0.033 & [0.021] & 8,583 & Men & \\
\hline & 0.034 & {$[0.056]$} & 1,518 & Women & $x$ \\
\hline & 0.080 & [0.059] & 1,114 & Men & $x$ \\
\hline \multirow[t]{4}{*}{ 6. Earnings in the fall } & $107^{*}$ & [65] & 18,015 & Women & \\
\hline & $304 * * *$ & [100] & 8,583 & Men & \\
\hline & 71 & [285] & 1,518 & Women & $x$ \\
\hline & 414 & [293] & 1,114 & Men & $x$ \\
\hline \multirow[t]{4}{*}{ 7. Employed in the third year } & -0.005 & [0.013] & 18,015 & Women & \\
\hline & 0.029 & [0.019] & 8,583 & Men & \\
\hline & -0.043 & [0.052] & 1,518 & Women & $x$ \\
\hline & -0.009 & {$[0.056]$} & 1,114 & Men & $x$ \\
\hline \multirow[t]{4}{*}{ 8. Earnings in the third year } & $706 * * *$ & {$[204]$} & 18,015 & Women & \\
\hline & $641^{*}$ & [355] & 8,583 & Men & \\
\hline & 872 & [811] & 1,518 & Women & $x$ \\
\hline & 1,310 & {$[1,072]$} & 1,114 & Men & $x$ \\
\hline
\end{tabular}

Note. Each row is for a separate regression. Coefficients are for the interaction of post-2008 indicator variable with full-time enrollment status in the first term. Robust standard errors are in brackets. All specifications include post-2008 indicator variable and full-time enrollment status in the first term. All regressions control for race/ethnicity, gender, high school graduation status, grade point average and credits earned in the first term, expected family contribution and Pell Grant amount in the first term, intent at college entry, and college and major fixed effects. Panels 5 to 8 also include year of work experience and its squared term as covariates.

$* * * p<.01, * * p<.05, * p<.1$. 
Table 9

DID Estimates of the Effect of YRP Eligibility by Age at Enrollment

\begin{tabular}{|c|c|c|c|c|c|}
\hline Outcomes & Post*Full-Time & SE & $N$ & $\begin{array}{c}\text { Age at } \\
\text { Enrollment }\end{array}$ & $\begin{array}{l}\text { Enrolled in Short } \\
\text { Term Programs }\end{array}$ \\
\hline \multirow[t]{4}{*}{ 1. Pell amount in summer } & $396^{* * *}$ & [17] & 16,300 & $\geq 20$ & \\
\hline & $190 * * *$ & [18] & 10,298 & $<20$ & \\
\hline & $481^{* * *}$ & {$[53]$} & 1,929 & $\geq 20$ & $x$ \\
\hline & $419 * * *$ & [97] & 703 & $<20$ & $x$ \\
\hline \multirow[t]{4}{*}{ 2. Credits earned in summer } & $0.871^{* * *}$ & [0.095] & 16,300 & $\geq 20$ & \\
\hline & $0.365^{* * *}$ & {$[0.096]$} & 10,298 & $<20$ & \\
\hline & $1.371^{* * *}$ & [0.303] & 1,929 & $\geq 20$ & $x$ \\
\hline & 0.788 & {$[0.484]$} & 703 & $<20$ & $x$ \\
\hline \multirow[t]{4}{*}{ 3. Earned certificate in one year } & $0.008^{*}$ & {$[0.004]$} & 16,300 & $\geq 20$ & \\
\hline & $-0.006 *$ & {$[0.004]$} & 10,298 & $<20$ & \\
\hline & $0.046^{* *}$ & [0.018] & 1,929 & $\geq 20$ & $x$ \\
\hline & 0.000 & {$[0.022]$} & 703 & $<20$ & $x$ \\
\hline \multirow[t]{4}{*}{ 4. Earned diploma in 2.5 years } & 0.007 & [0.005] & 16,300 & $\geq 20$ & \\
\hline & 0.001 & {$[0.004]$} & 10,298 & $<20$ & \\
\hline & -0.022 & [0.014] & 1,929 & $\geq 20$ & $x$ \\
\hline & 0.008 & {$[0.014]$} & 703 & $<20$ & $x$ \\
\hline \multirow[t]{4}{*}{ 5. Earned associate degree in 2.5 years } & $0.010^{*}$ & [0.005] & 16,300 & $\geq 20$ & \\
\hline & -0.002 & [0.004] & 10,298 & $<20$ & \\
\hline & 0.002 & {$[0.015]$} & 1,929 & $\geq 20$ & $x$ \\
\hline & 0.029 & {$[0.023]$} & 703 & $<20$ & $x$ \\
\hline \multirow[t]{4}{*}{ 5. Employed in the fall } & $0.028^{*}$ & {$[0.015]$} & 16,304 & $\geq 20$ & \\
\hline & $0.076^{* * *}$ & [0.019] & 10,294 & $<20$ & \\
\hline & 0.043 & {$[0.046]$} & 1,929 & $\geq 20$ & $x$ \\
\hline & 0.075 & [0.085] & 703 & $<20$ & $x$ \\
\hline \multirow[t]{4}{*}{ 6. Earnings in the fall } & $209^{* * *}$ & [79] & 16,304 & $\geq 20$ & \\
\hline & $190 * * *$ & [53] & 10,294 & $<20$ & \\
\hline & 203 & [247] & 1,929 & $\geq 20$ & $x$ \\
\hline & 208 & [234] & 703 & $<20$ & $x$ \\
\hline \multirow[t]{4}{*}{ 7. Employed in the third year } & 0.015 & [0.014] & 16,304 & $\geq 20$ & \\
\hline & 0.002 & [0.017] & 10,294 & $<20$ & \\
\hline & -0.029 & [0.043] & 1,929 & $\geq 20$ & $x$ \\
\hline & 0.036 & [0.078] & 703 & $<20$ & $x$ \\
\hline \multirow[t]{4}{*}{ 8. Earnings in the third year } & $1,330 * * *$ & [254] & 16,304 & $\geq 20$ & \\
\hline & -305 & [226] & 10,294 & $<20$ & \\
\hline & $1,497^{*}$ & [783] & 1,929 & $\geq 20$ & $x$ \\
\hline & 1,429 & {$[1,149]$} & 703 & $<20$ & $x$ \\
\hline
\end{tabular}

Note. Each row is for a separate regression. Coefficients are for the interaction of post-2008 indicator variable with full-time enrollment status in the first term. Robust standard errors are in brackets. All specifications include post-2008 indicator variable and full-time enrollment status in the first term. All regressions control for race/ethnicity, gender, high school graduation status, grade point average and credits earned in the first term, expected family contribution and Pell Grant amount in the first term, intent at college entry, and college and major fixed effects. Panels 5 to 8 also include year of work experience and its squared term as covariates.

$* * * p<.01, * * p<.05, * p<.1$. 


\subsection{Robustness Check}

The discussion of the estimation strategy in Section 5 provides some checks on the composition of full-time versus part-time students before and after the YRP implementation. Figure 6 illustrates a more robust test of the parallel trend assumption by showing the year-byyear interaction term on a set of outcomes controlling for enrollment status, enrolled year, and all other covariates in previous tables. The coefficient shown is similar to the Post $_{i} *$ Treat $_{i}$ interaction term shown in Tables 5 to 9. Instead of interacting Treat $_{i}$ with pre and post-2009 enrollment status, Treat $_{i}$ is interacted with the actual year of enrollment: Year $_{i} *$ Treat $_{i}$.

For the parallel trend assumption to hold, the coefficients from the 2009 cohort should ideally be different from the 2006, 2007, and 2008 cohorts, which should be similar to each other. At the very least, there should not be a steady upward or downward trend over time. Figure 6 shows support for this assumption and a strong effect of YRP eligibility for all academic outcomes except for diploma attainment.

While the recession does not seem to have influenced student characteristics or academic behavior, it may have influenced earnings three years from college enrollment. For example, the third year of the 2006 cohort is 2009, which occurs near the end of the recession. The third year of the 2009 cohort is 2012, by which time the economy is recovering. Figure 7 displays the earnings levels in the second and third year from college entry for the whole sample and shows a relatively flat trend across time and finds no violation of the parallel trend assumption.

The flat trend also points to a lack of effect of YRP eligibility on third year earnings. The lack of effect is possibly due to the short follow-up, and an effect may be more prominent if using earnings over five year from college entry. 
Figure 6

Event Study Plots of Academic Outcomes
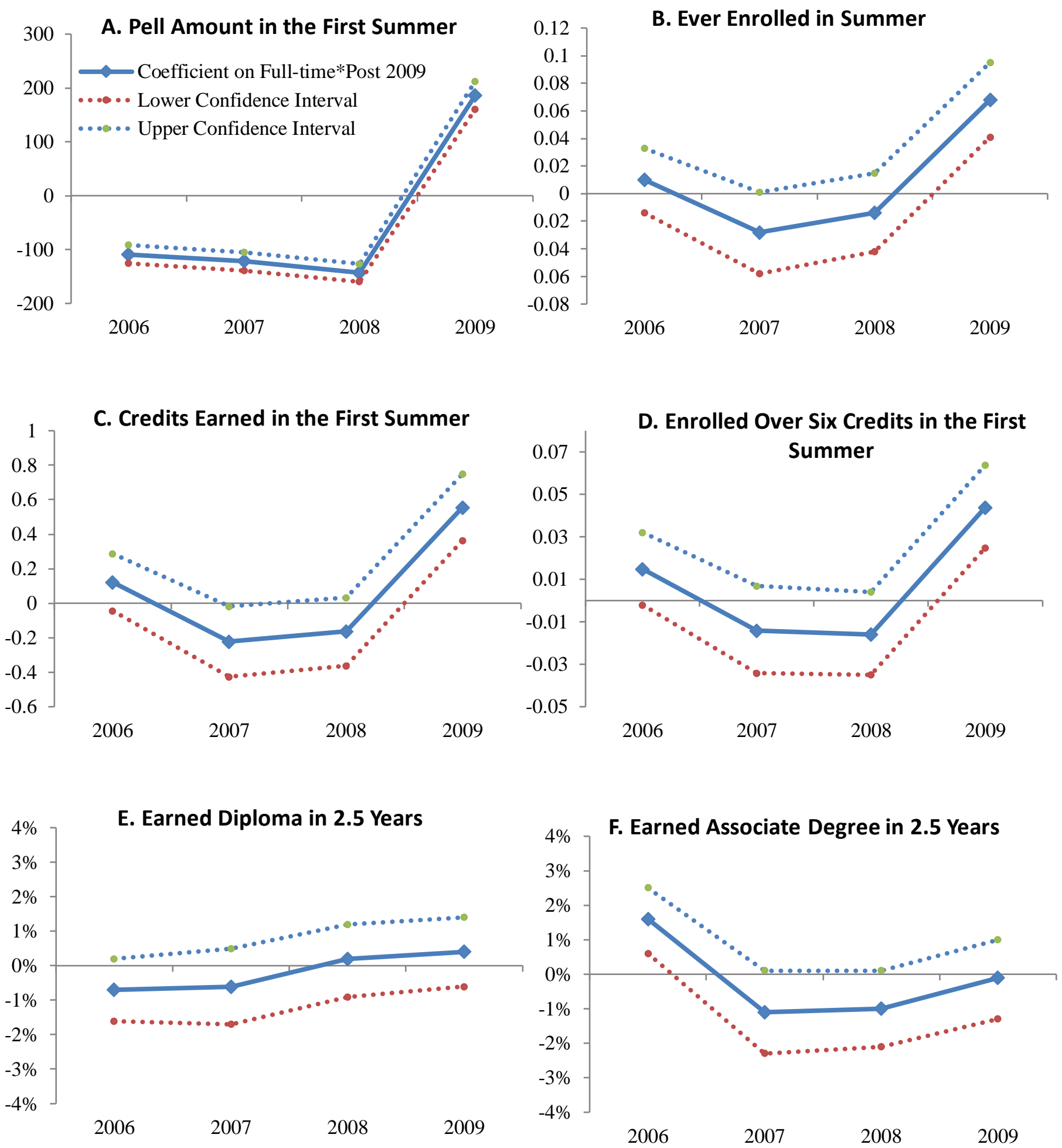
Figure 7

Event Study Plot of Earnings

\section{A. Earnings Second Year from College Entry}
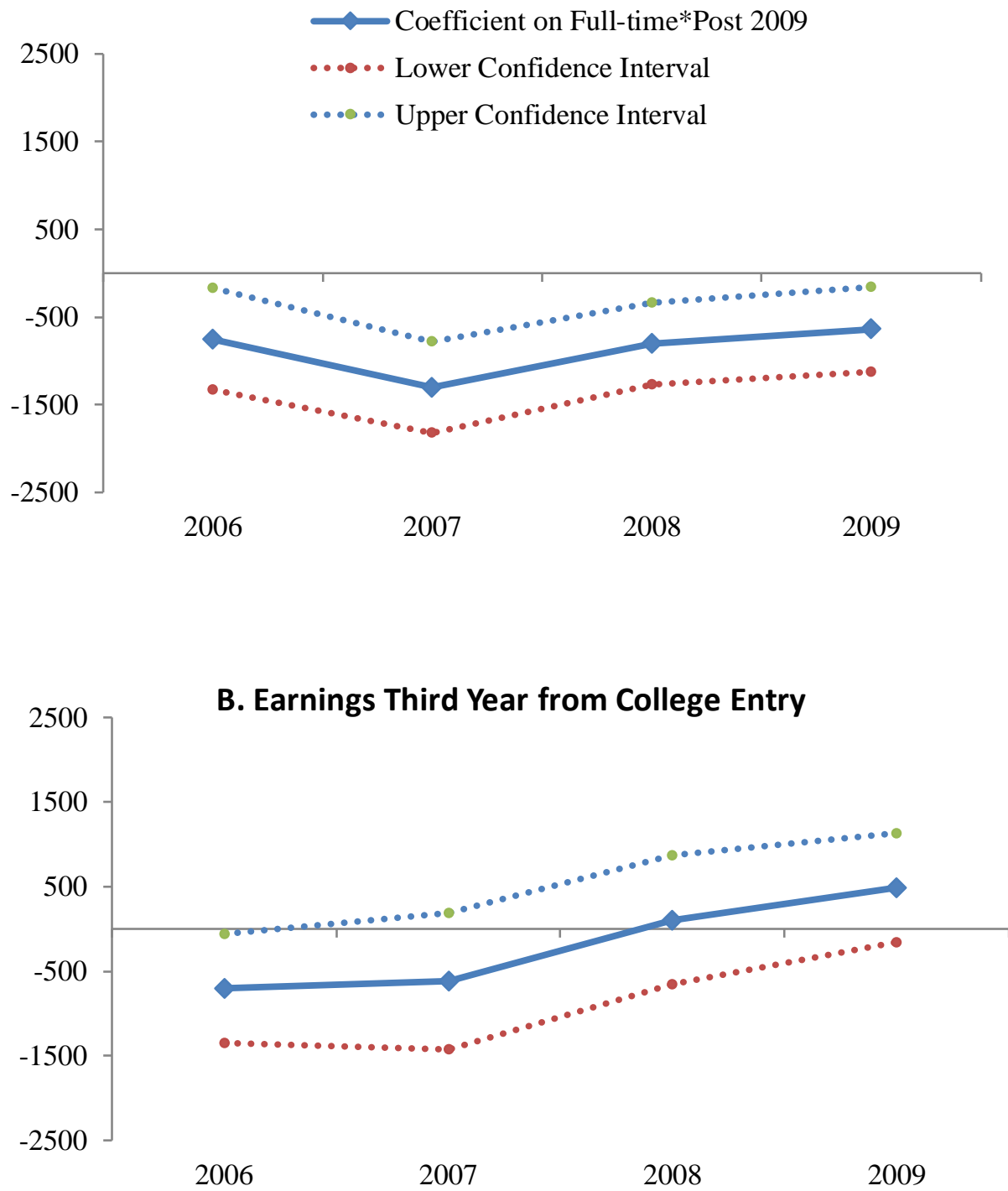
Overall, I find that students who are eligible for the YRP receive more Pell Grant funding in the summer, which then leads to gains in credits earned, completion rates, and earnings. YRP eligibility has almost no impact on loans, yet it reduces other state and institutional aid slightly. Subgroup analysis suggests that YRP eligibility has a larger impact on short-term credential completion rates for women and on the associate degree graduation rates for men. Older students also experience larger gains than younger students. Robustness checks show support for the parallel trend assumption.

\section{Conclusion}

As both college tuition and the enrollment of nontraditional students continue to rise, policies that can help students graduate in a timely matter become increasingly important. Students enrolled in community colleges are often older, employed full-time, minority, or first-generation students with low incomes who have higher financial constraints. The traditional Pell Grant covers only two semesters of full-time enrollment, leaving no support for low-income students who want to take courses in the summer. The short-lived YRP program gave extra summer funding to those who enrolled full-time in their prior two semesters. I exploit the exogenous variations of the timing of the introduction of the policy and its eligibility requirements to shed light on the impact of providing summer tuition support for community college students in a single state.

Using a DID approach, I find that for each \$1,000 of YRP disbursement per YRP eligible student, the likelihood of summer enrollment among YRP eligible students increases by 27 percentage points, the likelihood of associate degree completion increases by 2.2 percent points, and third year earnings from college entry increase by $\$ 2,182$. A "back-of-the-envelope" calculation using a tax rate of 15 percent indicates that the tax revenue raised from the earnings gains can pay back the cost of the program in around three years.

Breaking down the findings by age of enrollment shows that the completion and labor market gains accrue primarily to adult students who first enrolled at age 20 or above. The estimated increase in enrollment is substantially larger than the consensus result of a 3 to 6 percentage point gain per $\$ 1,000$ of grant disbursement from various 
sources found in research literature noted in Deming and Dynarski (2010). The main reason for this is that the current study includes all Pell eligible students in the sample, which avoids limiting the analysis to only those students around the Pell-eligible threshold or those who may have been hindered by the financial aid application. I also do not find any crowding-out effect on loans as Marx and Turner (2017) did. Additionally, the crowding-out effect on state and institutional aid that I do find seems too small to have a substantial influence on the positive outcomes.

Despite the limitations of short follow-up and the use of a single cohort of students eligible for the YRP, this paper provides the only evidence to date on the effect of the YRP on completion rates and labor market outcomes. It also provides an upper boundary for the effect of need-based grants. This research may provide important guidance to the federal government, policymakers, and advocacy groups as the YRP has been restored, beginning as early as summer 2017.

This paper also contributes to a broader set of conversations. Does more money matter in higher education? Results from this study suggests that it does and that adult students especially benefit from increased educational funding. Are there certain conditions that would maximize the impact of grants? Though not directly tested, the sample restrictions in this paper provide a kind of best-case scenario for grant aid, in which individuals with high financial need who experience no complications with aid applications comprise the sample, and the estimated results are better than those found in other grant studies. The YRP is also small enough that it does not trigger any substantial crowding-out effect on institutional aid or any changes in employment during college. These findings suggest that there exist some optimal conditions regarding the student composition, structure, and design of grant programs that can maximize their impact. And finally, are individuals willing to go to college year-round? This study shows that when provided an incentive, more students enroll in courses in the summer term in addition to the fall and spring semesters. In fact, as tuition continues to rise, finding ways to attend college year-round may become increasingly important for students with high credit constraints. 


\section{References}

Abraham, K. G., \& Clark, M. A. (2006). Financial aid and students’ college decisions evidence from the District of Columbia Tuition Assistance Grant Program. Journal of Human Resources, 41(3), 578-610.

Alon, S. (2011). Who benefits most from financial aid? The heterogeneous effect of need-based grants on students' college persistence. Social Science Quarterly, 92(3), 807-829.

Bannister, K., \& Kramer, D. (2015). The impact of the Year-Round Pell Grant on summer credit hour completion: A quasi-experimental case study at Hillsborough Community College (working paper). Gainesville, FL: University of Florida, College of Education.

Barr, A. (2015). From the battlefield to the schoolyard: The short-term impact of the post-9/11 GI Bill. Journal of Human Resources, 50(3), 580-613.

Bettinger, E. (2004). How financial aid effects persistence (NBER Working Paper No. 10242). Cambridge, MA: National Bureau of Economic Research. Retrieved from http://www.nber.org/papers/w10242.pdf.

Bettinger, E. P., Long, B. T., Oreopoulos, P., \& Sanbonmatsu, L. (2012). The role of application assistance and information in college decisions: Results from the H\&R Block FAFSA experiment. The Quarterly Journal of Economics, 127(3), 1205-1242.

Bound, J., \& Turner, S. (2002). Going to war and going to college: Did World War II and the GI Bill increase educational attainment for returning veterans? Journal of labor economics, 20(4), 784-815.

Carruthers, C. K., \& Welch, J. G. (2015). Not whether, but where? Pell Grants and college choices (No. 2015-04). Knoxville, TN: University of Tennessee.

Castleman, B. L., \& Long, B. T. (2016). Looking beyond enrollment: The causal effect of need-based grants on college access, persistence, and graduation. Journal of Labor Economics, 34(4), 1023-1073.

Congressional Budget Office. (2013). The federal Pell Grant program: Recent growth and policy options. Washington, DC: Author.

Deming, D., \& Dynarski, S. (2010). College aid. In P. B. Levine \& D. J. Zimmerman (Eds.), Targeting investments in children: Fighting poverty when resources are limited (pp. 283-302). Chicago, IL: University of Chicago Press.

Denning, J. T. (2017). Born under a lucky star: financial aid, college completion, labor supply, and credit constraints (Upjohn Institute Working Paper 17-267).

Kalamazoo, MI: W. E. Upjohn Institute for Employment Research. 
Dynarski, S. (2000). Hope for whom? Financial aid for the middle class and its impact on college attendance (NBER Working Paper No. 7756). Cambridge, MA: National Bureau of Economic Research.

Dynarski, S. (2003). Does aid matter? Measuring the effect of student aid on college attendance and completion. The American Economic Review, 3(1), 279-288

Dynarski, S. (2004). Who benefits from the education saving incentives? Income, educational expectations and the value of the 529 and Coverdell. National Tax Journal, 57(2), 359-383.

Dynarski, S., \& Scott- Clayton, J. (2006). The cost of complexity in Federal Student Aid: Lessons from optimal tax theory and behavioral economics. NBER Working Paper no. 12227. Cambridge, MA: National Bureau of Economic Research, May.

Dynarski, S., \& Scott-Clayton, J. (2008). Complexity and targeting in federal student aid: A quantitative analysis. In J. M. Poterba (Ed.), Tax policy and the economy (Vol. 22, pp. 109-150. Chicago, IL: University of Chicago Press.

Dynarski, S., \& Scott-Clayton, J. (2013). Financial aid policy: Lessons from research (NBER Working Paper No. 18710). Cambridge, MA: National Bureau of Education Research.

Friedmann, E. (2016, November). The effect of the year-round Pell Grant on enrollment. Presentation at the 2016 APPAM Fall Research Conference, Washington, DC.

Fullerton, D., \& Metcalf, G. E. (2002). Tax incidence. Handbook of public economics, 4, 1787-1872.

Goldrick-Rab, S., Kelchen, R., Harris, D., \& Benson, J. (2016). Reducing income inequality in educational attainment: Experimental evidence on the impact of financial aid on college completion. American Journal of Sociology, 121(6):1762-1817.

Hansen, W. L. (1983). Impact of student financial aid on access. In J. Fromkin (Ed.), The Crisis in Higher Education (pp. 84-96). New York, NY: Academy of Sciences.

Kane, T. J. (1994). College entry by Blacks since 1970: The role of college costs, family background, and the returns to education. Journal of political Economy, 102(5), 878-911.

Kane, T. J. (1995). Rising public college tuition and college entry: How well do public subsidies promote access to college? (NBER Working Paper No. 5164). Cambridge, MA: National Bureau of Economic Research.

Kane, T. J. (2003). A quasi-experimental estimate of the impact of financial aid on college-going (NBER Working Paper No. 9703). Cambridge, MA: National Bureau of Economic Research. 
Katsinas, S., Davis, J., Friedel, J., Koh, J., \& Grant, P. (2011). The impact of new Pell Grant restrictions on community colleges: A three state study of Alabama, Arkansas and Mississippi. Alabama: The University of Alabama Education Policy Center.

Katsinas, S., Davis, J., Koh, J., \& Grant, P. (2012). Pell Grant's vital role in lifting up Mississippi. Tuscaloosa, AL: The University of Alabama Education Policy Center.

Lovenheim, M., \& Owens, E. (2014). Does federal financial aid affect college enrollment? Evidence from drug offenders and the Higher Education Act of 1998. Journal of Urban Economics, 81(C), 1-13.

Marx, B., \& Turner, L. J. (2017). Borrowing trouble? Student loans, the cost of borrowing and implications for the effectiveness of need-based grant aid (NBER Working Paper No. 20850). Cambridge, MA: National Bureau of Economic Research.

Office of Management and Budget. (2011). Fiscal year 2012 terminations, reductions, and savings: Budget of the U.S. Government. Retrieved from http://www.whitehouse.gov/sites/default/files/omb/budget/fy2012/assets/trs.pdf

Rubin, R. B. (2011). The Pell and the poor: A regression-discontinuity analysis of ontime college enrollment. Research in Higher Education, 52(7), 675-692.

Schudde, L., \& Scott-Clayton, J. (2014). Pell Grants as performance-based aid? An examination of satisfactory academic progress requirements in the nation's largest need-based aid program (A CAPSEE Working Paper). New York, NY: Center for Analysis of Postsecondary Education and Employment.

Seftor, N. \& Turner, S. (2002). Back to school: Federal student aid policy and adult college enrollment. The Journal of Human Resources, 37(2), 336-352.

Turner, L. J. (2014). The road to Pell is paved with good intentions: The economic incidence of federal student grant aid. College Park, MD: University of Maryland, Department of Economics.

Turner, S. (1998). Does federal aid affect the price students pay for college? Evidence from the Pell Program (mimeo). Charlottesville, VA: University of Virginia.

U.S. Department of Education. (2011). Fiscal Year 2012 Department of Education Justification of Appropriation Estimates to the Congress: Student Financial Assistance. Retrieved from http://www2.ed.gov/about/overview/budget/budget12/justifications/index.html 
U.S. Department of Education, Office of Postsecondary Education. (2013). Federal Pell Grant program annual data reports. Retrieved from http://www2.ed.gov/finaid/prof/resources/data/pell-2012-13/pell-eoy-201213.html 